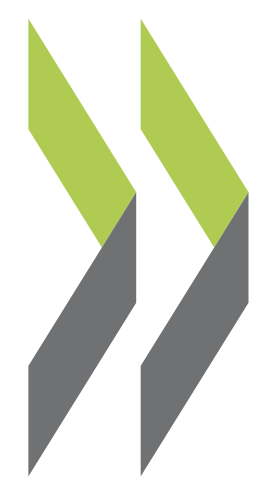

OECD Economics Department Working Papers No. 1514

A review of the empirical literature combining economic and environmental Antoine Dechezleprêtre, performance data at the micro-level 


\section{By Antoine Dechezleprêtre and Tobias Kruse}

OECD Working Papers should not be reported as representing the official views of the OECD or of its member countries. The opinions expressed and arguments employed are those of the author(s).

Authorised for publication by Luiz de Mello, Director, Policy Studies Branch, Economics Department.

All Economics Department Working Papers are available at www.oecd/eco/workingpapers.

JT03439876 
OECD Working Papers should not be reported as representing the official views of the OECD or of its member countries. The opinions expressed and arguments employed are those of the author(s).

Working Papers describe preliminary results or research in progress by the author(s) and are published to stimulate discussion on a broad range of issues on which the OECD works.

Comments on Working Papers are welcomed, and may be sent to OECD Economics Department, 2 rue André Pascal, 75775 Paris Cedex 16, France, or by e-mail to eco.contact@oecd.org.

All Economics Department Working Papers are available at www.oecd.org/eco/workingpapers.

This document and any map included herein are without prejudice to the status of or sovereignty over any territory, to the delimitation of international frontiers and boundaries and to the name of any territory, city or area.

On 3 May 2018, the OECD Council invited Lithuania to become a Member. At the time of preparation, the deposit of Lithuania's instrument of accession to the OECD Convention was pending and therefore Lithuania does not appear in the list of OECD Members and is not included in the OECD zone aggregates.

On 25 May 2018, the OECD Council invited Colombia to become a Member. At the time of preparation, the deposit of Colombia's instrument of accession to the OECD Convention was pending and therefore Colombia does not appear in the list of OECD Members and is not included in the OECD zone aggregates.

(C) OECD (2018)

You can copy, download or print OECD content for your own use, and you can include excerpts from OECD publications, databases and multimedia products in your own documents, presentations, blogs, websites and teaching materials, provided that suitable acknowledgment of OECD as source and copyright owner is given. All requests for commercial use and translation rights should be submitted to rights@,oecd.org 


\section{ABSTRACT/RÉSUMÉ \\ A review of the empirical literature combining economic and environmental performance data at the micro-level}

This article reviews the empirical literature combining economic and environmental performance data at the micro-level, i.e. firm- or facility-level. The literature has generally found a positive and statistically significant correlation between economic performance, as measured by stock market returns, and environmental performance, as measured by emissions of pollutants or adoption of international environmental standards. The main reason for this finding seems to be that firms that reduce their material and energy costs experience both better economic performance and lower emissions. There is also evidence that greener firms are able to attract more productive employees and face smaller costs of capital, and that the introduction of green products enhances firms' profitability.

Only a small and recent literature analyses the joint causal impact of environmental regulations on environmental and economic performance. Interestingly, this literature shows that environmental regulations tend to improve environmental performance while not weakening economic performance. However, the evidence so far is limited to a handful of environmental regulations that are not extremely stringent, so the result cannot be easily generalized. More research is needed to assess the joint effects of environmental regulations on environmental and economic performance, to explore the heterogeneity of these effects across sectors, countries and types of policies, and to understand which policy designs allow improving environmental quality while not altering the economic performance of regulated businesses.

JEL classification codes: Q50, Q58

Keywords : environmental performance, firm performance, microdata sources

\section{Examen des analyses empiriques associant des données sur les performances économique et environnementale au niveau micro-économique}

Il s'agit de passer en revue des travaux empiriques qui associent des données sur les performances économique et environnementale au niveau micro-économique, autrement dit à l'échelon des entreprises ou des installations. Dans l'ensemble, ces travaux font état d'une corrélation positive et statistiquement significative entre la performance économique (mesurée en particulier par la rentabilité boursière) et la performance environnementale (mesurée à l'aune des émissions de polluants ou de l'adoption de normes environnementales internationales). Cette conclusion semble avant tout tenir au fait que les entreprises qui réduisent leurs coûts matériels et énergétiques affichent simultanément un meilleur bilan économique et un plus faible niveau d'émissions. Il est également établi que les entreprises plus soucieuses de l'environnement sont en mesure d'attirer des salariés plus productifs, qu'elles supportent un coût du capital moins élevé et que le lancement de produits écologiques augmente leur rentabilité.

La littérature analysant conjointement l'incidence de la réglementation environnementale sur les performances environnementales et économiques des entreprises est plus récente et moins développée. Il est intéressant de constater que ces travaux font apparaître une tendance doublement vertueuse de la réglementation environnementale. Néanmoins, comme les études se sont limitées pour le moment à un faible nombre de dispositions en général peu contraignantes, il est difficile de généraliser ces résultats. D'autres travaux de recherche sont donc nécessaires pour permettre d'évaluer les effets conjugués de la réglementation environnementale sur les performances environnementales et économiques, d'étudier l'hétérogénéité de ces effets selon les secteurs, les pays et les caractéristiques de la politique poursuivie ainsi que de cerner les critères auxquels l'action publique doit satisfaire afin d'améliorer la qualité de l'environnement sans nuire aux résultats économiques des entreprises soumises à la réglementation.

Code de classification JEL : Q50, Q58

Mots-clés : performance environnementale, résultats des entreprises, sources de microdonnées. 


\section{Table of contents}

\section{A review of the empirical literature combining economic and environmental performance}

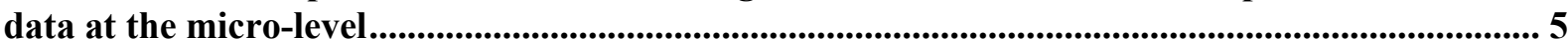

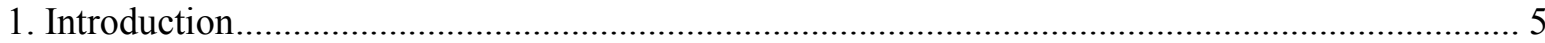

2. Is there a correlation between environmental and economic performance? Micro-level evidence.

2.1. Environmental performance and economic performance: evidence from stock returns........... 9

2.2. Understanding the drivers: why environmental performance can go hand in hand with economic performance

3. The joint impact of environmental regulations on environmental and economic performance..... 19

3.1. The joint impact of the EU ETS on carbon emissions and firm performance.......................... 19

3.2. The joint impact of the UK Climate Change Levy on carbon emissions and firm

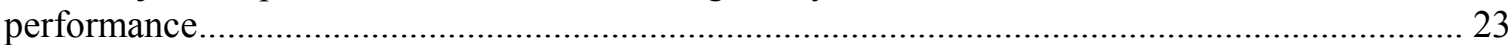

3.3. The joint impact of energy prices on economic and environmental performance ................... 24

3.4. The joint impact of environmental regulation on environmental and economic

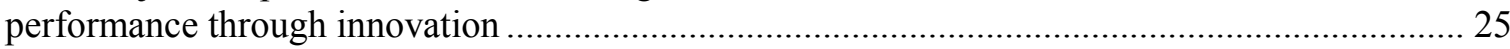

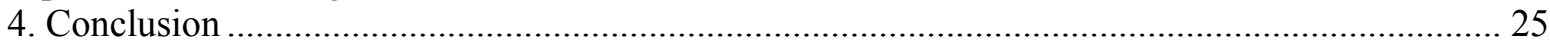

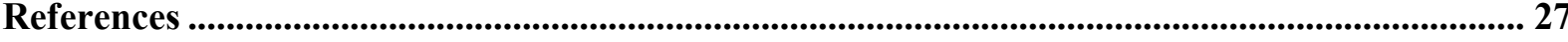

Annex A. Summary Table of Empirical Literature ................................................................................ 33

Papers reviewed in section 2.1: Environmental Performance and economic performance:

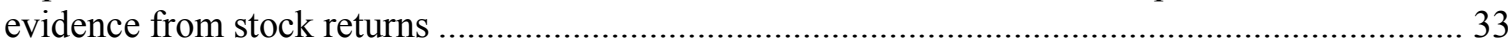

Papers reviewed in section 2.2: Understanding the drivers: why environmental performance can go hand in hand with economic performance

Papers reviewed in section 3: The joint impact of environmental regulations on environmental and economic performance 


\title{
A review of the empirical literature combining economic and environmental performance data at the micro-level
}

\author{
By Antoine Dechezleprêtre and Tobias Kruse ${ }^{1}$
}

\section{Introduction}

1. Ever since the first major environmental regulations were enacted in the $1970 \mathrm{~s}$, there have been concerns about their potential impacts on the performance of affected businesses. In particular, in a world characterised by increased integration in trade and capital flows, there is concern that differences in the stringency of environmental policies between countries and regions could affect companies' competitiveness. Countries or regions leading the action against environmental degradation worry that their lead might come at the cost of disadvantaging local businesses, and debates about the impacts of environmental regulations on competitiveness are often framed in terms of 'jobs versus the environment' (Morgenstern et al., 2002), particularly in countries and regions where declining manufacturing employment has become a contentious political issue. ${ }^{2}$

2. Environmental regulations are accused by some of jeopardising economic activity but are viewed by others as potential drivers of economic growth. Economists traditionally think of environmental regulations as adding costs to companies and slowing down productivity, because they divert resources away from productive investments such as investments in research and development and towards pollution-control activities (Rose, 1983; Schmalensee, 1993; Walley and Whitehead, 1994; Jaffe et al., 1995). Since it is reasonable to assume that firms would have reduced pollution in the absence of environmental regulation if it was profitable for them to do so, any environmental regulation is likely to come at a cost for businesses. If the stringency of policies differs across countries or regions, then environmental regulations may not only add costs to businesses, but may also affect the competitiveness of the domestic industry, putting some companies at a competitive disadvantage vis-à-vis their foreign competitors (Levinson and Taylor, 2008). The available empirical evidence shows that environmental regulations can lead to statistically significant adverse effects on trade, employment, plant location and productivity in the short run, in particular in a well-identified subset of pollution- and energy-intensive sectors, but that these impacts are small relative to general trends in production (see Dechezleprêtre and Sato, 2017, for a recent review dedicated specifically at the competitiveness effects of environmental regulations).

\footnotetext{
${ }^{1}$ Corresponding authors are: Antoine Dechezleprêtre (Antoine.Dechezlepretre@oecd.org) from the OECD Economics Department and the OECD Environment Directorate and Tobias Kruse (T.J.Kruse@1se.ac.uk) from the London School of Economics. The authors would like to thank Shardul Agrawala (OECD Environment Directorate), Dennis Dlugosch, Tomasz Koźluk, Giuseppe Nicoletti and Paul O'Brien (all from the OECD Economics Department) for their valuable comments, and Sarah Michelson for excellent editorial support (also from the OECD Economics Department).

${ }^{2}$ For example, in the United States, aggregate manufacturing jobs declined by 35 percent between 1998 and 2009, while total manufacturing sector production grew by 21 percent (Kahn and Mansur, 2013).
} 
3. However, a different view of the world has been articulated since the 1990s, with what has become widely known as the Porter hypothesis (Porter and van der Linde, 1995). The basic idea is that environmental regulations should foster innovation in environmentally-friendly technologies which would not have been developed otherwise, and the adoption of these new technologies could well, in the medium run, improve firms' productivity or allow regulated firms to achieve technological leadership.

4. Ambec et al. (2013) illustrate the main causal links involved in the Porter Hypothesis (see Figure 1). If an environmental regulation is well-designed and sufficiently flexible it may not only lead to improved environmental performance, but it may also lead to innovation offsets. These offsets can partially, or sometimes more than fully, offset any additional costs from the regulation, thereby increasing firms' business performance. Thus, according to the Porter Hypothesis, while effective environmental regulation improves the environmental performance of firms, well-designed regulation could also improve business performance.

Figure 1. Causal links involved in the Porter Hypothesis

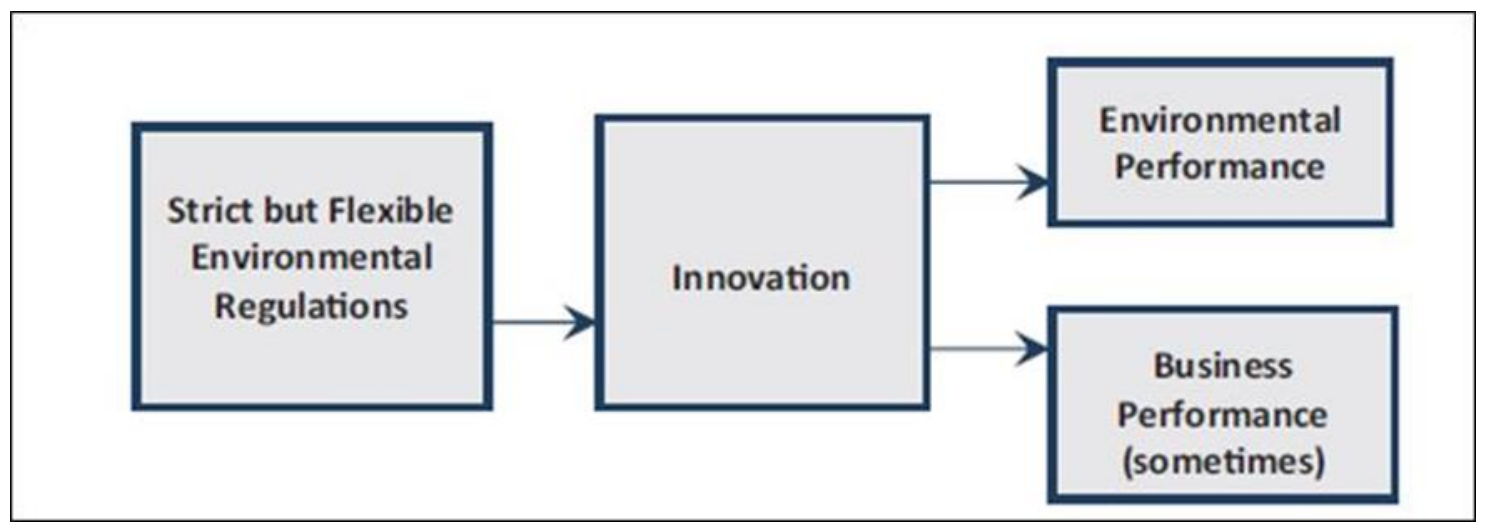

Source: Ambec et al. 2013

5. The Porter Hypothesis can take different forms according to the strength of the effect and the type of regulation (Jaffe and Palmer, 1997). The 'weak' version states that regulation will spur innovation. Thus, firms respond by innovating to reduce their costs from the environmental regulation (i.e. the first causal link in Figure 1). Yet, this weak version does not indicate if this innovation is good or bad for a firm's performance. The 'strong' version says that the regulation induces firms to find new products or processes that increase profits while complying with the regulation. According to this strong version, the benefits of the regulation more than offset its costs. This would make the regulation socially desirable even ignoring any environmental improvements arising from it. The 'narrow' version of the Porter Hypothesis states that only certain types of regulation will encourage innovation. The regulation needs to be sufficiently flexible and focus on the outcome (i.e. the emission reduction) rather than the process (i.e. the technology firms need to adopt) to induce innovation. Market-based regulations (taxation, emission trading schemes) would therefore be preferable to command-and-control regulations (Ambec et al. 2013). The firm-level empirical literature tends to fall into one of two categories: studies testing the weak version (i.e. the link between environmental regulation and innovation activity), and those testing the strong version (i.e. the impact of environmental regulation through innovation on business performance). The former is often assessed through $R \& D$ 
expenditures or the number of registered patents. The latter is often assessed through effects on productivity, profits or stock market returns.

6. The Porter Hypothesis was initially criticized for its lack of theoretical foundation, as it rests on the idea that firms ignore opportunities to improve their business performance. Following Porter and van der Linde (1995) a sizeable literature has emerged to provide the theoretical basis for the hypothesis, by highlighting the existence of additional market failures (beyond the environmental pollution externality). Examples for such market failures include asymmetric information within firms (Ambec and Barla, 2002), learningby-doing (Mohr, 2002), knowledge spillovers (Ambec and Barla, 2005), market power (Graeker, 2003), and investments with contractual incompleteness (Ambec and Barla, 2005). For example, in a theoretical model, Mohr (2002) assumes that the existence of knowledge spillovers prevents the replacement of an old polluting technology by a new, cleaner and more productive technology, as firms have a second-mover advantage if they wait for someone else to adopt. In this case, the introduction of an environmental regulation induces firms to switch to the new, cleaner technology, which simultaneously improves environmental quality and eventually increases productivity. This example illustrates the strong version of the Porter hypothesis is theoretically possible.

7. The growing importance of the debates over the many consequences of pollution on health, biodiversity loss, climate change, etc., and the potential negative consequences of environmental regulations on economic performance has led to a large number of studies that attempt to empirically quantify the impact of environmental regulations on the economic and the environmental performance of businesses. Multiple dimensions of economic performance of regulated businesses have been analysed, including productivity, innovation, employment, profitability, output and trade. Similarly, numerous environmental performance indicators have been used, including energy consumption, carbon emissions, emissions of various local pollutants (NOx, SOx, etc.) as well as composite indicators. These are typically used based on absolute values (e.g. emissions in tonnes, energy consumption in $\mathrm{kWh}$ ) or relative values (e.g. energy intensity).

8. Most studies have so far assessed the impact of environmental regulations on environmental and economic performance separately (for reviews, see Ambec et al., 2013; Arlinghaus, 2015; Dechezleprêtre and Sato, 2017; Jaffe et al., 1995; Lankoski, 2010; Iraldo et al., 2011; Endrikat et al., 2014; Friede et al. 2015; Martin et al., 2016; Cohen and Tubb, 2017). However, a critical input for policy makers implementing environmental regulations is an understanding of how such policies will impact both environmental quality and local businesses' economic performance. As a consequence, some recent studies have started to jointly analyse these dimensions. Another, more developed, strand of the literature asks if economic and environmental performance can go hand in hand, whether or not environmental performance is triggered by environmental regulations or driven by voluntary approaches.

9. The objective of this background paper is to provide an up-to-date review of this relatively recent empirical literature that combines economic and environmental performance data at the micro-level. For each of the papers surveyed, we discuss the pros and cons of the data used and present the empirical approach taken by the authors. A comprehensive table summarizes the studies surveyed.

10. Compared to ex-post analysis based on more aggregated data at sectoral, regional or national level, or to ex-ante Computable General Equilibrium models, analyses based on micro-data have several advantages. Sample sizes are typically much larger, allowing for more precisely estimated effects, smaller biases due to unobserved heterogeneity (for 
example, through the inclusion of firm-level fixed effects) and exploration of heterogeneous impacts across time or sectors. More generally, micro databases allow for a more credible identification of the treatment effects of a given regulation by applying the sort of quasi-experimental techniques that are most suited to assessing the causal impacts of environmental policies (List et al., 2003; Greenstone \& Gayer, 2009). For example, the European Union Emissions Trading System, which regulates the carbon emissions of around 12000 industrial sites across Europe, only regulates installations above a certain threshold in terms of production capacity. Therefore, it is possible to construct a control group of unregulated installations the size of which falls just below these administrative thresholds but are very similar, on all observable characteristics, to regulated installations. With a "treated" and a control group that are statistically identical before the introduction of the regulation, it is possible to identify the causal effect of the policy on regulated entities after the introduction of the regulation. Analyses based on micro-datasets also have drawbacks, however. In particular, they are ill-equipped to capture geographical or sectoral spillover effects and other general equilibrium effects. For example, it is not possible to analyse the potential impact of the EU ETS on unregulated firms facing higher energy prices because they buy electricity from regulated firms with the method presented above.

11. The paper is organized along the two main strands of the literature mentioned above. In the first section, we review the literature that analyses the direction of the correlation between environmental and economic performance at the firm level. The key feature of this literature is that it generally abstracts from the drivers of environmental performance, which could come from voluntary efforts of companies or be induced by environmental regulations. Because high environmental performance could be driven by profit- enhancing motivations (for example, improving energy efficiency to reduce input costs), a priori, we do not expect to find a negative relationship between environmental and economic performance. In the second section, we turn our attention to the joint impact of environmental regulations on environmental and economic performance. Here, if anything, we would expect regulations to improve environmental performance while weakening economic performance, bearing in mind that a Porter-like story could lead to a different outcome.

\section{Is there a correlation between environmental and economic performance? Micro- level evidence.}

12. There is a large literature on the relationship between environmental performance and economic performance at the firm level. However, this literature usually focuses on establishing correlations and does not properly address causality, i.e. the vast majority of studies cannot say with confidence whether improvements in firms' environmental performance cause improvements in firms' economic performance or the opposite, or if the direction is bidirectional. This is an important limitation because good environmental and economic performance could be driven by unobserved factors such as good management practices or the quality of the workforce, in which case the solution to improve both environmental and economic performance could reside in implementing policies in the non-environmental domain, for example education policies. Yet, establishing the direction of the correlation between environmental and economic performance at the micro level is interesting in its own right, given the widespread concern that they could be systematically negatively related. Note, finally, that because manufacturing firms represent the main source of pollution across countries, this literature generally focuses on the manufacturing sector. In comparison, the services sector is an understudied area. 


\subsection{Environmental performance and economic performance: evidence from stock returns.}

13. Numerous papers have analysed the sign of the correlation between environmental performance, sometimes defined by broad indicators, and economic performance, as measured by stock returns. The advantage of using stock returns as a measure of economic performance is that they represent an "objective" and comprehensive measure of economic performance, since stock prices should impound information about the firm's future prospects from a vast array of both financial and nonfinancial measures, such as net income, return on assets, operational data, etc. While other financial data, such as profit, capture a short term effect, stock prices will reflect investors' expectations of the long term effects of environmental performance. An obvious limitation of using stock return is that, by definition, data on economic performance is then limited to listed firms.

14. Many articles have surveyed this empirical literature and several meta-analyses are available (for example Wagner, 2001; Blanco et al., 2009; Horvathova, 2010; Albertini, 2013; Crifo and Forget, 2015). Overall, these surveys conclude that better environmental performance is associated with greater financial performance, although there is some variation in the results across studies. For example, Ambec and Lanoie (2007) survey 12 studies that rely on regression analysis of financial performance on environmental performance across multiple years. Different measures of economic performance are used, including Tobin's Q, return on assets, return on sales and return on equity. Environmental performance measures include toxic release inventory (TRI) emissions, ISO 14001 certification $^{3}$ and the adoption of other international environmental standards. Nine studies showed that better environmental performance is associated with better economic performance. Two studies show no impact, while one concluded that a negative relationship exists. In her review of the literature, Horvathova (2010) reports that about $15 \%$ of studies find a negative effect; about $30 \%$ of studies find no effect and $55 \%$ of studies find a positive effect. Blanco et al. (2009) provide an in-depth review of empirical studies that analyse the relationship between manufacturing firms' environmental performance or voluntary initiatives and their economic performance. They conclude on a prominent absence of penalty for being green, which is affected by the typology of the firm, the methods utilized for implementing environmental initiatives, the intensity of the abatement efforts and stockholders' valuation of green firms. In this sub-section, we rely heavily on these surveys and focus on their main results and on some of the key papers in that literature.

15. A crude measure of environmental performance is provided by international environmental management standards such as ISO 14001. The limitation of this indicator is that it is binary: within firms having adopted the standard, it is not possible to rank firms according to their performance. It is also a noisy indicator, as there probably is heterogeneity in the environmental performance of firms not adopting the standard. Bearing these limitations in mind, Hibiki et al. (2003) use data on 573 publicly-held firms in the manufacturing industry listed at the Tokyo Stock Exchange. They use adoption of the ISO14001 certification as a measure of environmental performance and consider the firm's Tobin's q as the measure of financial performance. They find that the introduction of the ISO14001 certification system is associated with a statistically significant increase in the market value of the firms in the manufacturing industry by $11 \%$ to $14 \%$. A similar finding

${ }^{3}$ ISO 14001 is a standardized environmental performance system that covers many aspects of environmental management such as life-cycle assessment and environmental performance indicators. 
is reported by Jacobs et al. (2010). Wagner and Blom (2011) examine nearly 500 firms from the UK and Germany and use the implementation of an environmental management system (EMS) as a proxy for companies' environmental performance. They find that the implementation of an EMS is only positively associated with firms' financial performance for already financially well-performing firms. A negative association exists for financially less-well performing firms. Yet, a limitation of their approach is that the implementation of the EMS does not provide information on the actual environmental outcomes, which remain unobserved.

16. Using toxic releases allows better measurement of environmental performance, and many studies have used this indicator. One of the most cited is by Konar and Cohen (2001), who relate the market value of 321 mostly manufacturing firms in the S\&P 500 to two objective measures of their environmental performance: the aggregate pounds of toxic chemicals emitted per dollar revenue of the firm and the number of environmental lawsuits pending against the firm in 1989. After controlling for variables traditionally thought to explain firm-level financial performance (market share of the firm, industry concentration ratio, sales growth, advertising intensity, research and development intensity, firm size, and the import intensity in the markets for the firms' products), they find that bad environmental performance is negatively correlated with the intangible asset value of firms. The average 'intangible liability' for firms in their sample is $\$ 380$ million-approximately $9 \%$ of the replacement value of tangible assets. This shows that legally emitted toxic chemicals have a significant effect on the intangible asset value of publicly traded companies. A $10 \%$ reduction in emissions of toxic chemicals is associated with a \$34 million increase in market value. The magnitude of these effects varies across industries, with larger losses accruing to the traditionally polluting industries. A similar result is reported by King and Lenox (2001). Other studies have obtained similar results based on improved methodologies, such as Al-Tuwaijri et al. (2004) who analyse the relationship between environmental and economic performance based on a cross-sectional dataset of 198 US firms. They measure a firm's economic performance using an industry-adjusted annual return, which is calculated as the change in stock price during the year (adjusted for dividends), scaled by the beginning-of-year stock price minus the industry median return (based on two-digit SIC codes). This annual industry-adjusted stock return thus represents a measure of the firm's current-period economic performance relative to other firms in the same industry. To measure environmental performance, they use the ratio of toxic waste recycled to total toxic waste generated (thus, if a firm introduces a pollution-abatement process, decreasing the total amount of toxic waste generated, or if the firm adopts processes that recycle toxic waste, such as closed-loop cooling systems, environmental performance will increase). They find that better environmental performance is significantly associated with better economic performance. This result is consistent with the idea that investors view good environmental performance as an intangible asset. They find a similar result when directly using stock price as a measure of environmental performance.

17. While studies using toxic emissions as a measure of environmental performance seem to report a positive relationship between environmental and stock market performance, it is interesting to note that this might not be the case for other environmental outcomes. For example, Fujii et al. (2013) examine the relationship between environmental performance and economic performance in Japanese manufacturing firms. The environmental performance indicators include $\mathrm{CO} 2$ emissions and the aggregate toxic risk associated with chemical emissions relative to sales. Return on assets (ROA), Return on Sales (ROS) and Capital Turnover (CT) are used as indicators of economic performance. 
Fujii et al. (2013) find heterogeneous effects for the different environmental pollutants. The environmental performance based on $\mathrm{CO} 2$ emissions contributed positively to ROA. For toxic releases they demonstrate a significant inverted U-shaped relationship with ROA and CT. While Fujii et al. (2013) solely analyse manufacturing industries, Trumpp and Guenther (2017) include service industries as well. Furthermore, they allow for nonlinearities in the relationship by adding quadratic terms in their regressions. Having a global dataset consisting of 2361 firm-years with 696 unique firms, they find a U-shaped relationship between carbon performance and profitability as well as between waste intensity and profitability. Hence, the level of environmental performance affects the direction of the relationship between the two variables. Trumpp and Guenther (2017) conclude that only after passing an environmental performance threshold it starts to 'pay to be green'.

18. Using a 2003 OECD survey, Darnall (2009) examines the relationship between self-reported firm-specific environmental performance and self-reported profitability using survey responses from 4188 facility managers from seven OECD countries (Canada, France, Germany, Hungary, Japan, Norway, United States). To obtain a measure of environmental performance they asked whether the facility manager had experienced a change in environmental impacts per unit of output in the last three years. These were reported separately for six environmental impacts. ${ }^{4}$ For information on the financial performance of the facility, managers were asked about any changes in the facility's profits over the past three years. Furthermore, facility managers were asked to rate the environmental policy stringency to which they were subject. They find a positive relationship between environmental performance and financial performance and observe a negative correlation between facility-specific perceived policy stringency and profits. Yet, these findings are limited by the reliability of the managers' responses, as well as the crosssectional nature of the study.

19. In a series of studies, Rassier and Earnhart (2010a; 2010b; 2015) analyse the extent to which firm-specific emissions limitations has heterogeneous effects on firms' actual profitability and investors' expectations on firms' future profitability. ${ }^{5}$ Across all studies, they examine the effects of facility-specific wastewater discharge limits regulated by the US EPA. ${ }^{6}$ Although the authors do not observe actual emissions, the enforced facilityspecific discharge limits are used as a close proxy for facilities' emissions. ${ }^{7}$ Using return on sales (ROS) as their financial performance measure, Rassier and Earnhart (2010a) use quarterly data on 59 firms and annual data of 73 firms to examine the relationship between financial performance and discharge limits. For both datasets, they find a negative relationship between clean water regulation and firms' actual profitability. A 10\%

${ }^{4}$ The six environmental outcome variables are: Natural resource use, solid waste, waste-water effluent, air pollution, GHG emissions, and overall environmental impact.

${ }^{5}$ For a comprehensive summary on the differences between the studies see Table C.1 in Rassier and Earnhart (2015).

${ }^{6}$ All papers use wastewater discharge limits for biochemical oxygen demand (BOD) and total suspended solids (TSS). These are conventional and highly prevalent pollutants, which receive regulatory scrutiny by the EPA.

7 The facility-specific discharge limits are based on state-or industry-level water quality standards. These state water quality standards differ across water bodies and time. Moreover, the discharge limits differ across facilities and time since the assimilative capacity of water bodies differs across location and time (Rassier and Earnhart, 2015: 133). 
reduction in the average permitted discharge leads to a decline in the return on sales of between $0.8 \%$ and $2.7 \%$. Rassier and Earnhart (2010b) examine the effect of permitted wastewater discharge levels on future expected financial performance of 54 manufacturing firms in the US using annual data. They find that tighter permitted discharge limits significantly decrease expectations of future profits. Rassier and Earnhart (2015) build upon their earlier studies and estimate the effects on actual and expected profitability jointly using a sample of 740 observations from 47 unique firms using quarterly data. They are able to improve upon their earlier work by including additional control variables. Their results on actual profitability are consistent with the Porter hypothesis indicating that tighter clean water regulation is positively associated with profitability. However, their results on expected profitability suggest that investors appear to expect a negative relationship between clean water regulation and profitability. This finding suggests that investors do not value the positive effect of regulation on firms' profitability, but instead seem to expect a negative impact on firms' profitability from tighter regulation. The authors explain these results with behavioural biases and lack of information among investors.

20. An important question in understanding the relationship between environmental and economic performance is whether improving environmental performance induces costs in the short run but benefits in the longer run. A few studies seem to confirm this hypothesis. Khanna and Damon (1999) evaluate the impact of the EPA's 33/50 program on the economic performance of firms in the US chemical industry relative to non-participants. The 33/50 Program is a voluntary initiative launched by the EPA in 1991 to encourage firms to reduce their emissions of 17 high-priority toxic chemicals. Of the firms emitting one or more of these 17 chemicals in $1988,14 \%$ had pledged their participation in the program by 1993. After controlling for the effects of firm-specific factors, the authors find that an increased probability of participation in the program is significantly associated both with a decline in return on investment and with an increase in market variables (excess of market value over the book value of assets normalized by sales). Therefore, while the immediate impact of participation in the program on profits is negative relative to the profits of non-participants, participating companies, in the long run, are expected to be more profitable, and therefore market variables perform better. Horvathova (2012) uses a sample of 136 Czech firms observed over several years. Her indicator of environmental performance is a composite indicator constructed using the European Pollutant Release and Transfer Register (EPRTR) which provides data on 93 pollutants releases to air, water and land as well as off-site transfers of waste and of pollutants in waste water from industrial facilities in the European Union Member States. Economic performance is measured using Return on Assets and Return on Equity. The results indicate that better environmental performance decreases financial performance in the subsequent year, but increases financial performance after two years. The net (cumulative) effect seems negative, but the author does not test whether it is statistically significantly so. Rassier and Earnhart (2011) also focus on the inter-temporal effect of environmental performance on financial performance. They study U.S. firms and measure the environmental performance by permitted wastewater discharge limits and use the returns on sales as the financial performance measure. In contrast to Horvathova (2012), they find that lower emissions improve firm financial performance both in the short and the long run with a stronger effect in the long run.

21. Some recent studies have evaluated the impact of participation in the European Union's Emissions Trading Scheme on stock returns. Participation in the EU ETS is not a direct measure of environmental performance, but since these companies face a price on their carbon emissions, they should emit less than a comparable firm not covered by the 
regulation. However, what has been assessed so far is mostly the impact of free allocations on stock returns. For example, Oestreich and Tsiakas (2015) look at a sample of 65 German firms and find that firms that received free carbon emission allowances on average significantly outperformed firms that did not. This suggests the presence of a large and statistically significant carbon premium, which is mainly explained by the higher cash flows due to the free allocation of carbon emission allowances. Veith et al. (2009) also reported that during Phase I of the EU ETS (2005-2007), there was a positive correlation between carbon prices and the returns on stocks of major European power companies. This correlation suggests that power companies profited from freely allocated permits and could pass-through a large enough share of the permit price. Similarly, Bushnell et al. (2013) show that the fall of the permit price in April 2006 led to a drop in stock prices of companies in both carbon- and electricity-intensive industries. Martin et al. (2014b) show that the free allocation of emission permits lead to substantial overcompensation for a given risk of carbon leakage (the relocation of carbon-intensive industries to non-regulated jurisdictions). They show that permit auctioning in combination with a systematic and targeted industry compensation scheme would lead to a more desirable outcome, preventing firm relocation and carbon leakage at a lower cost, compared to the existing free distribution of permits. It is not possible to conclude based on these studies that better environmental performance (through the inclusion in the EU ETS, which forces firms to control their carbon emissions) is associated with higher stock returns. Rather, it is the design of the policy (i.e. distribution of free allowances based on grandfathering) which explains the positive correlation between inclusion in the EU ETS and stock market performance.

\subsection{Understanding the drivers: why environmental performance can go hand in hand with economic performance}

22. As shown in the previous section, the vast literature that has looked empirically at the relationship between environmental and economic performance based on stock market data points to a positive correlation between environmental performance and stock returns. Therefore, it is interesting to understand why such a positive relationship emerges empirically. We explore this question in this section.

\subsubsection{Theoretical background}

23. While the conventional wisdom regarding environmental protection is that it comes at an additional cost imposed on firms, which should thus lead to weaker economic performance, this plausible prediction has been challenged over the past two decades following the famous paper by Porter \& van der Linde (1995), who have argued that improving a company's environmental performance can lead to better economic or financial performance, and not necessarily to an increase in cost. This paper did not provide any strong theoretical motivation for that prediction, but many authors have subsequently provided theoretical grounding for it.

24. Ambec and Lanoie (2008) argue that there are at least seven ways in which improving a company's environmental performance can lead to better economic performance (see Figure 2). This could happen through either an increase in revenue or a reduction in production costs. Better environmental performance could lead to an increase in revenues through three channels: (a) better access to certain markets; (b) differentiating products; and (c) selling pollution-control technology. Better environmental performance can lead to a reduction in costs in four categories: (a) risk management and relations with external stakeholders; (b) cost of material, energy, and services; (c) cost of capital; and (d) 
cost of labour. In the following sub-sections we present the empirical literature that has analysed these potential determinants of the positive relationship between environmental and economic performance uncovered by studies reviewed in section 2.1 .

Figure 2. Potential positive links between environmental and economic performance

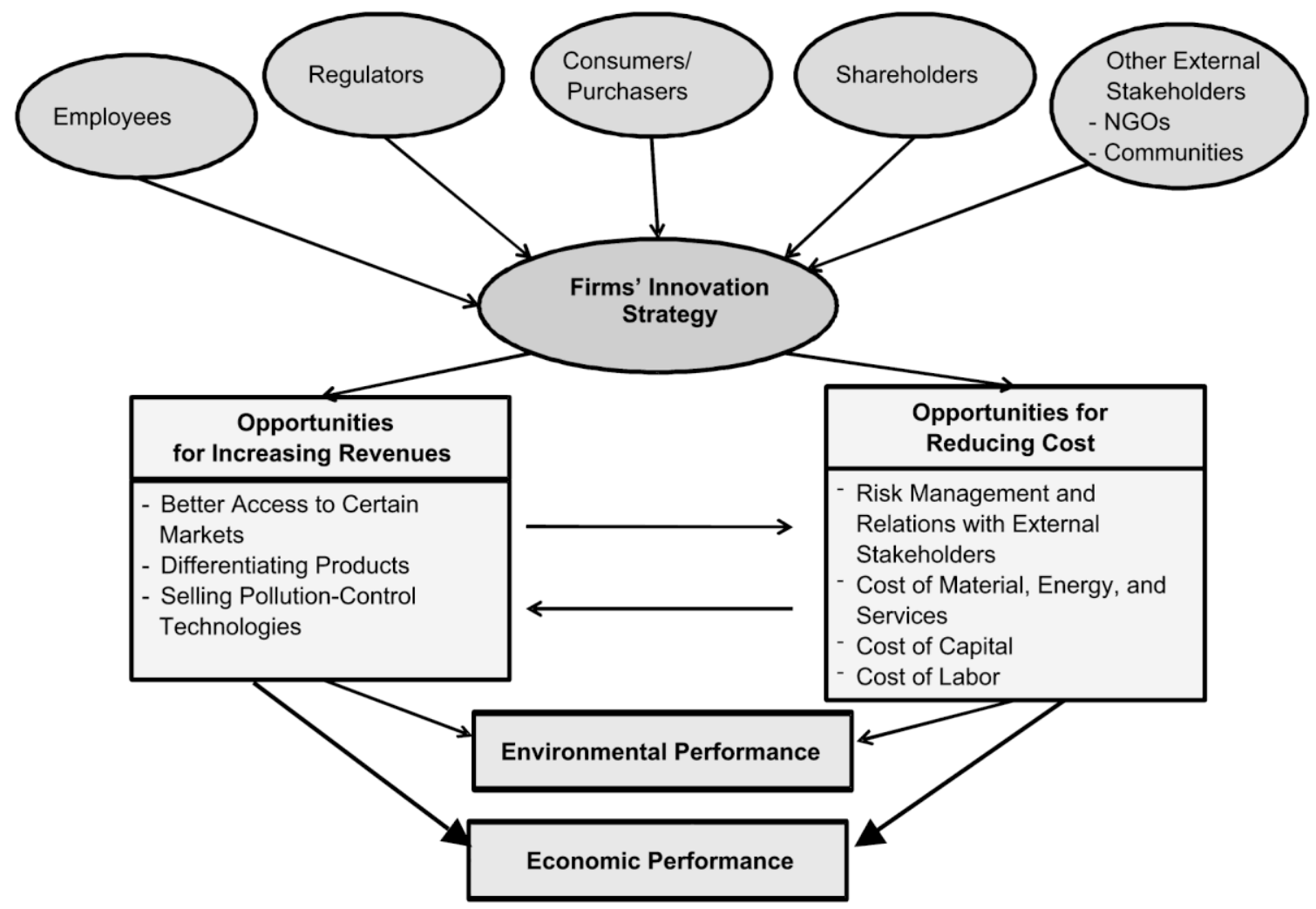

Source: Ambec and Lanoie, 2008.

\subsubsection{Better economic performance through increased revenues}

25. The empirical evidence on environmental performance providing better access to certain markets is usually available from case studies with small samples. An exception is the paper by Antweiler and Harrison (2003) which tests the prediction that 'environmentally-leveraged' firms with consumer market exposure experience larger emission reductions. To do this, the authors analyse firms' response to the publication of Canada's National Pollutant Release Inventory (NPRI) between 1993 and 1999. NPRI covers around 2500 facilities who have to report their emissions of 192 pollutants into the air, water, land, and subsoil. The main problem faced by the authors is that they do not observe purchases from households and businesses at a sufficiently high level of disaggregation and they cannot link products to individual plants. Thus, they rely on the idea that, if consumers use the NPRI to identify facilities with high levels of pollution and to identify the companies that own them, the only way they can then punish these firms is by not buying any products from these firms since they cannot link products to particular facilities. Therefore, multi-product firms will experience a "spillover" effect through which high-emission products will negatively impact sales of low-emission products. They find that companies that are relatively more exposed to final consumers and that have a greater 
diversity of emissions across products (thus, are more "environmentally-leveraged") reduce their releases to air and transfers of wastes off site most strongly, but also interestingly increase more less visible releases to subsoil via underground injection.

26. Only a handful of papers analyse the correlation between the introduction of green products and firms' economic performance. This small literature has mostly focused on the relationship between introduction of new green products and employment growth. Rennings and Zwick (2002) and Rennings et al. (2004) examine the determinants of employment changes due to the introduction of new environment-friendly products. The data stem from telephone surveys in five European countries. 1594 interviews were conducted with environmentally innovative establishments from both the industry and services sectors. The authors classify environmental innovations of these establishments into new products and services, new processes, adoption of end-of-pipe technologies, and enhanced recycling. Based on results of discrete choice models, they show that if the most important environmental innovation is a product or a service innovation, i.e. the introduction of a new green product or service, it has a significantly positive effect on the probability that the firm increases its number of employees. However, if the most important environmental innovation is an end-of-pipe innovation, this increases the likelihood that the firm decreases its employment base. Horbach (2010) also explores employment effects of environmental product innovations at the firm level. The empirical analysis is based on the establishment panel of the Institute for Employment Research (Nuremberg) and includes 900 firms operating in environmental sectors and 12400 firms operating in nonenvironmental fields. The econometric results show that the influence of environmental innovation activities on the employment development is significantly positive. Firms in the environmental sector that developed new or modified products from 2002 to 2003 increased their employment from 2003 to 2005. The magnitude of the impact of innovation on employment seems to be larger than in non-environmental fields. The authors explain that this difference may be due to the fact that environmental technologies and products are characterized by an earlier market development phase compared to other innovative products connected with higher employment dynamics.

27. A recent study conducted by Palmer and Truong (2017) examines the relationship between the introduction of new products based on green technologies and firm profitability. "New technological green products" include any new product that builds on technological advances to limit or lower its environmental footprint or that of other products, for instance, through improved energy efficiency or waste management. While past studies have mostly used survey-based questionnaires to capture firms' new green products, Palmer and Truong (2017) use the press releases of actual new product introductions instead of relying on respondents' reporting which may be less reliable and less objective. The sample consists of 1020 technological green new product introductions emanating from 79 global firms between 2007 and 2012. The authors find a positive correlation between technological green NPIs and firm profitability, as measured by turnover or return on total capital. Since the authors do not control for new product innovations in general, this result could simply reflect the impact of new product innovations in general. However, when the authors use as an alternative explanatory variable the ratio of technological green NPIs to the total number of NPIs, they interestingly still find a positive effect, although only significant at the $10 \%$ level, suggesting that there might be extra profitability associated with a higher proportion of green products. Overall, the findings point to the existence of financial incentives for firms to use green technologies to limit the environmental impact of new product introductions. 


\subsubsection{Improved economic performance through reduced cost of inputs}

28. While there is so far only limited empirical evidence to back the hypothesis that increased environmental performance could cause an increase in revenue, or this evidence is based on small samples from which no general conclusion can be made, much more evidence is available on the cost side.

\section{Energy and materials}

29. Perhaps the most natural way in which better environmental performance could be associated with greater economic performance is through reduced cost of inputs, and in particular of energy. The empirical evidence available confirms this prior. Existing studies examine this question often through measures of firms' productivity (Total Factor Productivity or TFP). This captures the effect on firms' output from the introduction of an environmental regulation with a constant set of production inputs. According to the Porter Hypothesis, regulation may increase productivity, as it reduces firms' wasteful energy inputs. Firms facing some costly regulation may also react by improving the productivity of other inputs such as labour. The opposing view is that regulation reduces firms' productivity as it poses additional constraints on their production. Overall, the empirical literature shows that environmental regulations do not appear to be a major driver of firms' productivity.

30. Shadbegian and Gray (2003) examine the determinants of environmental performance at 68 US paper mills, measured by air pollution emissions per unit of output. They find that plants with lower emissions are also generally more efficient: plants with 10 percent higher productivity have 2.5 percent lower emissions. This indicates that productive efficiency and pollution abatement efficiency are complements, with better managers being better at both production and abatement (rather than substitutes, with managers concentrating on productive efficiency at the expense of their abatement performance). Shadbegian and Gray (2006) also report a positive correlation between production efficiency and pollution abatement efficiency in the US paper, oil and steel industries, even after controlling for observable factors.

31. Bloom et al. (2010) examine how the quality of management relates both to the energy intensity of firms (and thus, lower energy costs per unit of output) and total factor productivity by matching firm-level information on management practices to production and energy usage data from the UK census for the establishments owned by these firms. They find a robust negative correlation between management practices and energy intensity on the one hand, and a positive correlation between management practices and total-factor productivity on the other hand. In terms of magnitude, improving management practices from the $25^{\text {th }}$ to the $75^{\text {th }}$ percentile is associated with a $17.4 \%$ reduction in energy intensity and with a $3.7 \%$ increase in total-factor productivity. Thus, better economic performance as measured by TFP is associated with lower energy intensity. Martin et al. (2012) report a similar result when focusing specifically on management practices related to climate change 190 randomly selected manufacturing plants in the UK. The authors interviewed the managers of these plants to derive measures for the companies' practices in the areas of energy use and climate change and combined their responses with energy consumption data from the Annual Respondents Database (ARD) and economic performance data from official business microdata. They find that climate friendly management practices, as measured by an index constructed from survey responses, are associated with lower energy intensity and higher productivity. 
32. Similarly, Horbach and Rennings (2013) show that the introduction of cleaner production processes innovations leads to a higher employment within the firm. Noticeably however, end-of-pipe technologies (in particular air and water process innovations) have a negative impact on employment. This confirms an earlier result by Pfeiffer and Rennings (2001) who show that cleaner production processes are more likely to increase employment compared to end-of-pipe technologies. Van Leeuwen and Mohnen (2017) obtain similar results from a panel of Dutch manufacturing firms for the period 2000-2008. They show that only production process innovations are positively correlated with firms' productivity, whereas end-of-pipe innovations are negatively correlated. Kumar and Managi (2010) also find a positive relationship between environmental and economic performance. They analyse the US emission allowance trading scheme for $\mathrm{SO}_{2}$ emissions, which was introduced as part of the 1990 US Clean Air Act Amendment (USCAAA). Again, as in the case of the EU ETS, participation in the $\mathrm{SO}_{2}$ trading scheme is not a direct measure of environmental performance. However, since these companies face a price on their firmspecific $\mathrm{SO}_{2}$ emissions, they should emit less than in the absence of the trading scheme. They find that between 1995 and 2005 electricity-generating plants are able to increase electricity output and reduce $\mathrm{SO} 2$ emissions due to the allowance trading scheme.

33. Gray and Shadbegian (2003) and Shadbegian and Gray (2005) find insignificant effects for the relationship between firms' pollution abatement investments and productivity. Assuming that pollution abatement investments result in actual pollution abatement, their indicator is used as a proxy for firms' environmental performance. The former examine 116 US pulp and paper plants between 1979 and 1990 and observe that the effect of pollution abatement investments on productivity differs substantially by plants' technology. On average, they observe that plants with higher abatement costs have lower productivity levels. Yet, this negative relationship between higher abatement costs and lower productivity levels is largely driven by mills, which incorporate a pulping process. For mills without such technology, the impact is negligible. Similarly, Shadbegian and Gray (2005) examine the contribution of pollution abatement expenditure to firms' productivity for 68 paper mills, 55 oil refineries and 27 steel mills. In their sample, they are able to distinguish between productive and pollution abatement expenditures for each production input. They find little evidence that abatement inputs contribute to production with nearly all coefficients being insignificant.

34. Ayerbe and Gorriz (2001), Broberg et al. (2013), and Sanchez-Vargas et al. (2013) find modest negative relationships between firms' environmental performance and productivity. Ayerbe and Gorriz (2001) examine whether pollution abatement investments designated for compliance with environmental performance- and technology standards impact firms' productivity. In their sample of 53 large Spanish companies, they find a weak negative relationship with firms' productivity. Yet, the authors conclude that this finding might be specific to their small sample and the specific pollution abatement technology.

35. Broberg et al. (2013) use a stochastic frontier model to estimate the relationship between environmental protection investment and technical efficiency in five Swedish manufacturing industries. Environmental protection investments are again used as a proxy for environmental performance, assuming that such investments result in actual environmental protection. They observe a weak negative relationship between environmental investments and technical efficiency. Sanchez-Vargas et al. (2013) use a 2002 cross-sectional dataset of 900 Mexican manufacturing plants to identify nonlinearities in the relationship between plants' pollution abatement expenditure and productivity. They find an overall negative relationship between pollution abatement expenditure and firms' 
productivity. However, the relationship is nonlinear and depending on plant size: the negative effect is larger for small firms and nearly negligible for larger firms.

36. Alongside papers based on regression analysis of past data, a new literature is emerging that uses experimental data to assess the environmental-economic performance of firms. Gosnell et al. (2017) implemented an experiment in partnership with Virgin Atlantic Airlines in order to test the impact of various incentives (monitoring, performance information, personal targets, and prosocial incentives) on fuel efficiency of their captains in three key flight areas: pre-flight (aircraft fuel load), in-flight (fuel-efficiently between take-off and landing), and post-flight (taxi). They find that, by simply informing the captains that the academic researchers and VAA Fuel Efficiency personnel overseeing the study are measuring their behaviours on three dimensions, captains considerably reduce fuel consumption: captains in this experimental group significantly increased the implementation of Efficient Flight and Efficient Taxi by nearly 50 percent from the preexperimental period. These behavioural changes generated more than 7700 tons of fuel saved for the airline over the eight-month experimental period (i.e. \$6.1 million in 2014 prices), which translates to approximately 24500 tons of $\mathrm{CO} 2$ abated. Moreover, monitoring and targets also induce captains to improve efficiency in all three key flight areas. The study provides the lowest ever calculated marginal abatement cost per ton of $\mathrm{CO} 2$, at negative $\$ 250$ (i.e. $\$ 250$ savings per ton abated), showing that airlines can at the same time improve environmental as well as economic performance. Experimental studies of this sort are only emerging, but constitute a fruitful avenue for future research.

\section{Labour costs}

37. Some authors have also argued that better environmental performance can lead to a reduction in the cost of labour, because environmentally-friendly companies are able to attract and retain motivated employees who work harder for lower wages. Indeed, if people prefer their employer to be socially responsible, they will, if faced with a choice between two otherwise identical job offers with equal pay, choose the employer they find more responsible. Therefore, to make those people indifferent, the less responsible employer must offer a higher wage. There is empirical support for the idea that social responsibility of firms is valued by employees. For example, it has been reported that job satisfaction is substantially higher when top management is perceived as strongly supporting ethical behaviour. Lanfranchi and Pekovic (2012) use data on 11600 employees at 7700 French firms and find that employees of firms that have adopted voluntary environmental standards report a significantly higher feeling of usefulness at work. Nyborg, and Zhang (2013) carried out a survey on 100000 Norwegian employees and show that firms with higher Corporate Social Responsibility pay substantially, and statistically significantly, lower wages. Three studies using data for French firms and employees find that, for firms that have adopted voluntary environmental standards, employees are more likely to work uncompensated overtime hours (Lanfranchi and Pekovic, 2012), labour productivity is higher (Delmas and Pekovic, 2013), and difficulties with recruitment are smaller (Grolleau et al., 2012). It is not clear, however, whether this is driven by self-selection of more productive and motivated employees into CSR firms or whether working for a socially responsible employer in itself increases motivation at work. This literature is still in its infancy and future research might enable to shed light on this issue.

\section{Cost of capital}

38. Better environmental performance could be associated with a lower cost of capital, in particular because of lower exposition to environmental risk and liabilities. For example, 
El Ghoul et al. (2011) examine the effect of corporate social responsibility (CSR) on the cost of equity capital for a sample of around 2000 US firms. They find that firms with better CSR scores exhibit cheaper equity financing. Attig et al. (2013) find that credit rating agencies tend to award relatively high ratings to firms with good social performance. Cheng et al. (2013) show that firms with better CSR performance face significantly lower capital constraints. Goss and Roberts (2011) use a sample of 3996 loans to US firms and find that firms with social responsibility concerns pay between 7 and 18 basis points more than firms that are more responsible. A common limitation to all these studies is that they use indicators of CSR that include not only environmental performance but also other measures of social responsibility, such as responsible practices towards employees. Therefore, it is not possible to determine whether the relationship stems from better environmental performance or better performing or more committed employees.

\section{The joint impact of environmental regulations on environmental and economic performance}

39. A large literature has analysed the impacts of environmental regulations on environmental performance, while another strand of the literature has looked at the consequences on economic performance. In comparison, the literature analysing these two outcomes jointly at the level of firms or plants is limited. Almost all of the literature that does this has focused on climate change regulations, and within this literature, most papers analyse the effect of the European Union Emissions Trading System (EU ETS). We start with these papers before reviewing the rest of the literature.

\subsection{The joint impact of the EU ETS on carbon emissions and firm performance}

40. In 2005, the European Union Emissions Trading System (EU ETS) - the EU's flagship climate change policy - was launched in 24 countries across Europe. The policy regulates the carbon emissions of around 12000 installations, together representing roughly $40 \%$ of the EU's total greenhouse gas emissions, by allocating pollution permits to these installations, which can then be freely traded on an international permit market. The objective of this cap-and-trade programme is to achieve a set reduction of aggregate $\mathrm{CO} 2$ emissions at minimal cost. Power stations and industrial plants across Europe were classified according to their main activity: combustion, cement, paper and pulp, and so on. The EU ETS offers a unique opportunity to investigate the causal impact of environmental policy on both environmental and economic performance. It is the first and largest environmental policy initiative of its kind anywhere in the world, which, by itself, would make it an interesting case to study. But more important is the fact that, in order to control administrative costs, the EU ETS was designed to cover only large installations. Activityspecific size criteria determine which installations would be included in the EU ETS. For instance, only combustion installations with a yearly thermal input exceeding $20 \mathrm{MWh}$ are covered. Firms operating smaller installations are not covered by EU ETS regulations. It is therefore possible to exploit these installation-level inclusion criteria to compare firms or installations with similar environmental and economic performance prior to the introduction of the EU ETS, but which have fallen under different regulatory regimes since 2005. This provides an opportunity to apply the sort of quasi-experimental techniques most suited to assessing the causal impacts of environmental policies (List et al., 2003; Greenstone \& Gayer, 2009). 
41. The central outcome of interest for a policy such as the EU ETS are CO2 emissions. The only source for representative emissions data for both EU ETS and non-EU ETS plants are confidential business surveys maintained by government statistical agencies. Access to these datasets is restricted and subject to disclosure control. This explains why few studies so far have been set out to understand the impact of the EU ETS on the economic and environmental performance of regulated installations, through the use of comprehensive plant-level data. To date, four studies have explored the joint effect of the EU ETS on firms' and installations' environmental and economic performance, respectively in France, Germany, Norway and Lithuania.

\section{France}

42. Using comprehensive plant-level data for around 9500 French manufacturing firms, Wagner et al. (2014) explore the economic and environmental response of plants to the introduction of the EU ETS. The analysis is based on a combination of energy consumption and economic performance data at the facility and firm level. The EACEI (Enquete Annuelle sur les Consommations d'Energie dans l'Industrie) is a survey conducted annually in France. It provides quantities and values of energy consumed by energy type (electricity, vapour, natural gas, coal, lignite, coke, butane, propane, fuel oil, heating oil, wood, etc.). About 12000 establishments are part of the sample: all industrial establishments employing 20 employees or more in the most energy consuming sectors, all establishments with more than 250 employees, and a sample of establishments with employment between 20 and 249 employees in sectors that are not energy intensive. Fuel consumption information at the plant level is then converted into carbon emissions based on widely available carbon content data on the various fuels consumed. This dataset is combined with EAE (Enquête Annuelle des Entreprises), which collects balance-sheet data at the firm level on turnover, employment, capital, and aggregate wages, as well as information about firm location and industry classification. The data are available for all firms with more than 20 employees and all the plants of those firms. Finally, the data is matched on the European Union Transaction Log, which contains the list of all installations regulated under the EU ETS. Notably, in France, the national registry is managed by the Caisse des Dépôts and their website provides a link between the EUTL permit identifier (GIDIC) and the French unique firm identifier SIREN, allowing a quasi-perfect matching of the two databases.

43. To examine the causal effect of the EU ETS on environmental and economic performance, Wagner et al. (2014) combine matching with difference-in-differences. For each EU ETS-regulated plant, they use propensity score matching to identify the most similar non-EU ETS plant (nearest neighbour), which becomes part of the control group and helps determining what would have been the behaviour of regulated plants, had they not been regulated. Ideally, one would want to directly use the production capacity of the plants to create such pairs, since it is production capacity pre-EU ETS that determines inclusion into the system. However, this variable is not observed by the researchers. Therefore, they use carbon intensity of each plant in the year 1999, the announcement year of the EU ETS, as the main matching variable. They also match each plant exactly on sector at the NACE two-digit level. This means that each EU ETS plant is compared with a nonEU ETS plant operating in the same two-digit sector and having the same carbon intensity before the announcement of the EU ETS. A potential problem is the absence of size variables in the matching process, which might induce the authors to compare plants of very different sizes and thus very different on unobserved characteristics as well. 
44. Their results suggest that ETS-regulated manufacturing plants in France reduced emissions by an average of $15 \%$. The analysis shows no effect of the EU ETS during Phase I (2005-2007) and a 15\% reduction in emissions during Phase II compared to unregulated plants. Having facility level data, Wagner et al. (2014) can explore if there is any evidence of within firm leakage for firms with both unregulated and regulated facilities. One would expect that it would be easier for such firms to shift emissions to unregulated plants as they are incurring less transaction costs than firms who have no pre-existing links with unregulated facilities. However, they do not find any evidence for such within-firm carbon emissions reallocation effects. Instead, the reduction in emissions appears to be driven mostly by reductions in the carbon-intensity of production. In particular, about half of the reduction in emissions can be accounted for by an increase in the share of gas, which is less carbon intensive than coal and oil.

45. In terms of economic outcomes, Wagner et al. (2014) do not find any statistically significant impact on employment, suggesting that the EU ETS was effective at reducing carbon emissions of regulated plants with no statistically significant effect on domestic jobs.

\section{Germany}

46. Petrick and Wagner (2014) analyse the causal impact of the EU ETS on German manufacturing firms using comprehensive panel data from the German production census. Contrary to Wagner et al. (2014) who use data on French plants, their analysis is conducted at the firm level. They are able to match 1658 EU ETS facilities to the German AFiD company database. They use propensity score matching to select a group of comparable but unregulated firms, and base this on a comparably much richer set of observable pretreatment characteristics: $\mathrm{CO} 2$ emissions, gross output, export share of output, number of employees, average wage, the squares of all these variables, and dummies for two-digit industry (WZ classification) and state (Bundesland) wherein the firm is located.

47. Petrick and Wagner (2014) find robust evidence that phase II of the EU ETS caused treated firms to reduce their emissions by a substantial margin, in the order of 25 to 28 percentage points more than non-treated firms. In parallel, carbon intensity fell between 18 and 30 percentage points faster at EU ETS firms than at the control firms. This suggests that firms responded to the introduction of the EU ETS mainly by adjusting intensity, not scale. Furthermore, firms were found to have reduced their carbon emissions by switching from high-carbon fuels (natural gas and oil) to low-carbon fuels (electricity).

48. Turning to economic outcomes, Petrick and Wagner (2014) find no statistically significant effects of the EU ETS on employment. In a word, putting a price on carbon does not seem to come at the expense of domestic job destruction. As for gross output, they estimate that the EU ETS increased gross output at regulated firms by a statistically significant amount of between 4 and 7 percent. While this allows the authors to reject the hypothesis that the EU ETS caused firms to reduce the scale of production, the positive effect on gross output is surprising and consistent with both firms producing more or charging higher prices. Unfortunately, they cannot distinguish between these two responses for lack of a measure of physical output. Similarly, they reject the hypothesis that the EU ETS caused regulated firms to reduce their overall exports, but they even find that the EU ETS increased total exports by $6 \%$ to $11 \%$ for phase I and by $7 \%$ to $18 \%$ for phase II. Again, it is not clear whether the increase in exports reflects an increase in the volume of shipments or a price increase, or both. 
Norway

49. Klemetsen et al. (2016) examine the impacts of the EU ETS on the environmental and economic performance of Norwegian plants. They use plant level data from the Norwegian Environment Agency for the period 2001 to 2013 on annual emissions of all Norwegian plants regulated by the Norwegian ETS or the Norwegian Pollution Control Act, including emissions of $\mathrm{CO} 2, \mathrm{~N} 2 \mathrm{O}$ and PFCs (measured in $\mathrm{CO}_{2}$ equivalents). This dataset allows the authors to identify which plants were regulated by the EU ETS. It is then supplemented with annual plant level data from Statistics Norway on number of employees, man hours, value added, energy use and prices and industry classification. The sample includes 665 plants of which 150 plants are regulated by the EU ETS.

50. Propensity score matching techniques are used to construct a control group of similar but unregulated plants. Exact matching is done on type of pollutant $(\mathrm{CO} 2, \mathrm{~N} 2 \mathrm{O}$ or PFCs) and on industry classification at two-digit level. Continuous matching variables include emissions levels of emissions (as a proxy for capacity limit) and number of employees (as a measure of plant size) in the pre-treatment year 2001. Not all EU ETS regulated plants can be matched, hence the final matched sample includes 152 plants of which 72 plants are regulated by the EU ETS. However, it is notable that the control group still appears quite different from the treatment group even after matching with, for example, an average $\mathrm{CO} 2$ intensity of $62.1 \%$ in the treatment group and only $6.8 \%$ in the control group. Therefore, it is questionable how comparable the treated and control groups are in this study.

51. Klemetsen et al. (2016) analyse the effect of the EU ETS on emission levels and intensity (defined as emissions divided by man hours). They find weak evidence that regulated plants reduced emissions by a large amount (-30\%) in the EU ETS' second phase, and no evidence that emission intensity decreased in any of the phases. This suggests that, to the extent that the ETS participation led to emissions reductions in phase II, this occurred through reduced activity level rather than through reduced emissions intensity.

52. Klemetsen et al. (2016) consider two measures of economic performance: value added at factor prices, which is the plant's annual gross production value minus the cost of intermediates plus subsidies and minus taxes (except VAT), and labour productivity, defined as value added at factor prices per man hour. For Phase II, the estimated effects on both value added and productivity are positive and significant, and suggest increases of around $25 \%$. These surprising effects could result from the impact that free allowances or cost pass-through may have had on value added.

Lithuania

53. Finally, Jaraite and Di Maria (2016) analyse the impact of the EU ETS on CO2 emissions and economic performance in Lithuania for the period 2005-2010 using plantlevel data. They compare 41 EU ETS firms with 312 non-EU ETS firms matched through propensity score-matching. They find no reductions in emissions and a slight improvement in emissions intensity in 2006-2007, but their data does not allow them to study effects on emissions beyond 2007. When it comes to economic performance, Jaraite and Di Maria (2016) find no significant impacts of the EU ETS on Lithuanian firms' profitability.

\section{Pan-European studies}

54. At present, only one paper has analysed the joint effect of the EU ETS on CO2 emissions and economic performance based on data from the entire European Union. Abrell et al. (2011) use data on 2101 firms across Europe representing around 60\% of EU 
ETS regulated emissions to assess reductions in $\mathrm{CO} 2$ emissions induced by the transition from Phase I to Phase II of the programme, which occurred in 2008. They find that emission reductions were 3.6\% higher between 2007 and 2008 than between 2005 and 2006, a difference which they attribute to the increased stringency of the regulation. This finding is robust to controlling for turnover, employment, profits, and industry and country trends, suggesting that the reduction in emissions is due to the change in stringency from Phase I to Phase II (i.e. the lower allocation of permits) and not to a decrease in production. Abrell et al. (2011) then apply a nearest-neighbour matching procedure to their sample of EU ETS firms and find that the policy caused a small but significant decrease in employment of 0.9 percent between 2004 and 2008. One limitation of the matching procedure is that, as Martin et al. (2014a) explain, taking control firms only from non-regulated sectors is problematic, because of the possible non-random selection of which sectors were regulated under the EU ETS, hence the study is likely to suffer from selection bias at the sector level.

\subsection{The joint impact of the UK Climate Change Levy on carbon emissions and firm performance}

55. The UK Climate Change Levy (CCL) is a carbon tax associated with a scheme of voluntary agreements (called Climate Change Agreements) available to plants in selected energy intensive industries. Upon joining a CCA, a plant adopts a specific target for energy consumption or carbon emissions in exchange for an $80 \%$ discount on the tax liability under the CCL. Martin et al. (2014a) analyse the impact of the CCL on energy use, emissions and economic performance of regulated plants for the period 2001-2004 based on micro-level data.

56. The identification strategy of the paper is to compare changes in outcomes between fully-taxed CCL plants and CCA plants which pay the reduced tax rate. Since plants selfselect themselves into a CCA, it is not possible to implement a straightforward differencein-differences (DiD) strategy. However, a key feature of eligibility for CCAs is that plants needed to emit pollutants subject to environmental regulation under the Pollution Prevention and Control (PPC) act which pre-dated the CCL. This variation in eligibility across plants can hence be used as an instrument for CCA participation. Indeed, since eligibility is based on pollution intensity, many energy intensive industries are ineligible for the tax discount. For instance, textile wet processing was an eligible activity thanks to its high pollution emissions, but not so dry processing which, although energy intensive, emits no pollution regulated under PPC. Similarly, both the production and the recycling of glass containers are very energy-intensive processes. However, since only the former is pollution-intensive, glass container recycling was not eligible for CCA participation. This institutional feature induces exogenous variation in the probability of treatment even within narrowly defined, energy-intensive industrial sectors.

57. The core dataset is the Annual Respondents Database (ARD), an annual production survey that covers about 10000 plants in the manufacturing sector. Energy use comes from the Quarterly Fuels Inquiry (QFI), a survey among a panel of about 1000 manufacturing plants which can be matched to the ARD. Information on CCA participation comes from both the DEFRA and HM Revenue and Customs (HMRC) websites. Finally, data for the instrumental variable comes from the European Pollution Emissions Register (EPER). The final dataset includes 6886 plants, among which 1079 have detailed information on fuel consumption by type.

58. Instrumental variable estimations show that the CCL had a strong negative impact on energy intensity $(-18 \%)$, particularly at larger and more energy intensive plants. This 
seems mainly driven by a reduction in electricity use which translates into a negative impact on $\mathrm{CO} 2$ emissions. The results suggest that firms substituted labour for energy and increased output prices in response to the energy price increase. In contrast, the authors do not find any statistically significant impacts of the tax on employment, revenue (gross output) or total factor productivity (TFP). Similarly, no evidence is found that the CCL accelerated plant exit.

\subsection{The joint impact of energy prices on economic and environmental performance}

59. To examine more generally the effect of energy prices on firms' environmental and economic performance, Marin and Vona (2017) use three rich datasets provided by the French Statistical Office covering the period 1997 to 2010: the EACAI survey for establishment-level energy purchases and consumption, DADS (Déclaration Annuelle des Données Sociales) for data on employment and wages, and FARES-FICUS for information on firms' balance sheets. By combining these datasets they can use differences across establishments in energy intensities, -prices, and -mixes. Hereby, energy intensities provide a proxy for establishments' exposure to energy price changes, and the energy mix (i.e. the use of electricity versus natural gas and other fuels) indicates establishments' technology and the relative exposure to price changes for the respective energy source. Energy use and $\mathrm{CO}_{2}$ emissions capture firms' environmental impact, and employment, wages and productivity are used as economic outcomes.

60. To estimate the effect of electricity prices on firms' environmental and economic outcome variables Marin and Vona (2017) use both a simple fixed effects model, as well as an Instrumental Variable (IV) specification. The latter is important to address concerns of endogeneity due to non-observed variables, which could bias the results of the simple fixed effects model. Such variables could be firm-specific demand shocks or technological change as a response to changes in energy prices. These variables are likely to be correlated with both the outcome variables and energy prices, resulting in a biased estimation of the model. To overcome this concern the authors require an instrumental variable that is correlated with the exogenous variation in energy prices but not related to establishmentspecific technological responses to changes in energy prices. They use a combination of the nationwide price of energy with a fixed firm-specific energy mix, which does not change over time (shift-share instrument). Changes in nationwide prices are uncorrelated with firm-specific demand shocks dealing with the first concern. Since most endogenous technological change operates through changes in the mix of energy sources, holding fixed the energy mix addresses the second source of potential bias.

61. In their preferred specification with the Instrumental Variable, Marin and Vona (2017) identify a trade-off between environmental and economic goals: A $10 \%$ increase in establishment-level energy prices, leads to a reduction in energy consumption and $\mathrm{CO} 2$ emissions by $6.4 \%$ and $11.5 \%$ respectively. Yet, the same increase in energy prices also leads to a modest negative effect on employment $(-2.6 \%)$, wages $(-0.4 \%)$ and firm's productivity $(-1.1 \%)$. The negative employment impacts differ across sectors with energyintensive and trade-exposed sectors experiencing the largest decline. However, preliminary evidence shows a substantial reallocation of production inputs between establishments of the same firm as a response to energy price changes. This gives reasons to believe that the estimated employment impacts are upper bounds. Some of the employees, which are observed as losing their job at one establishment, are simply relocated to another establishment within the same firm. 


\subsection{The joint impact of environmental regulation on environmental and economic performance through innovation}

62. Several studies have examined the causality chain implied by the Porter hypothesis - from regulation to innovation to profitability - and find that the positive effect of innovation on business performance does not outweigh the negative effect of the regulation itself (Lanoie et al., 2011). Thus, environmental regulation is costly, but it is less costly than if one were to consider only the direct costs of the regulation itself and ignore the ability of innovation to mitigate those costs. This is because over time, regulation-induced innovations that improve a firm's resource efficiency in terms of material or energy consumption, have a positive impact on profitability (Rexhauser and Rammer, 2014).

63. Porter and van der Linde (1995) also argue that countries that take early action in environmental protection will induce higher costs for domestic firms in the short run, but that the induced innovation will generate economic benefits in the long run by giving domestic firms a competitive advantage over foreign firms, which will be constrained by the same regulation later on. However, to our knowledge, no study has empirically analysed whether this first-mover advantage actually leads to competitiveness improvements in the long-run.

\section{Conclusion}

64. This paper has reviewed the available empirical literature combining economic and environmental performance data at the micro-level. Two strands of the literature can be distinguished.

65. The first strand of literature analyses the sign of the correlation between environmental and economic performance at the firm level. While numerous measures of environmental performance are used, the measure of economic performance usually used is financial performance based on market value data. While market data has the advantage of being widely available, it is also - by definition - restricted to listed firms and, as such, the results may be affected by a sample selection bias and might not be representative of the population of firms, in particular of smaller firms that are typically not listed. Moreover, this literature generally abstracts from the drivers of environmental performance, which could come from voluntary efforts of companies or be induced by environmental regulations. Because high environmental performance could be driven by profit-enhancing motivations (for example, improving energy efficiency to reduce input costs), it is perhaps not surprising that many studies report a positive relationship between environmental and economic performance.

66. The second strand of the literature analyses the joint impact of environmental regulations on environmental and economic performance. Because economists traditionally think of environmental regulations as forcing firms away from the optimum by requiring them to implement costly abatement activities that divert resources away from productive investments, it is all the more surprising and interesting that this literature usually finds that environmental regulations tend to improve environmental performance while not weakening economic performance. However, no study confirms the so-called strong version of the Porter hypothesis, which postulates that environmental regulations can improve at the same time environmental and economic performance.

67. Both strands of the literature have limitations. In addition to using small samples that are usually restricted by the availability of market data, the first strand suffers from weaker methodologies which make the establishment of a causal link (from environmental 
performance to economic performance) difficult. In contrast, because the implementation of environmental regulations can sometimes be claimed to be exogenous (this is in particular the case for the European Union Emissions Trading System, which uses arbitrary administrative thresholds to determine inclusion), the second strand of the literature can identify a causal link from environmental regulation to environmental and economic performance.

68. Compared to the first strand, the second strand of the literature is still in this infancy. Most studies have used a single policy experiment, the European Union Emissions Trading System, and focus on a single country. Only one multi-country study is available. Yet, only cross-country studies would enable researchers to determine which combination of public policies (instruments for environmental policy, innovation policy, fiscal policy, etc.) works best at inducing the greatest benefits in terms of improved environmental performance, while implying the smallest costs or, potentially, the greatest improvements in terms of economic performance (productivity, etc.). Carrying out a multi-country analysis would seem a natural extension of the existing literature and could make an important contribution in this respect. As an international organisation, the OECD is wellpositioned to make such a contribution in the near future. 


\section{References}

Abrell, J., A. Ndoye Faye, and G. Zachmann (2011), "Assessing the impact of the EU ETS using firm level data”, Bruegel Working Paper, No 2011/08.

Al-Tuwaijri, S., T. E. Christensen and K.E Hughes II (2004), "The relations among environmental disclosure, environmental performance, and economic performance: a simultaneous equations approach", Accounting, Organizations and Society, Volume 29, Issues 5-6, July-August 2004, Pages 447-471, ISSN 0361-3682, http://dx.doi.org/10.1016/S0361-3682(03)00032-1.

Albertini, E. (2013), "Does environmental management improve financial performance? A metaanalytical review", Organization and Environment, 26 (4): 431-457.

Ambec, S. and P. Lanoie (2007), "When and why does it pay to be green?", Discussion Paper, No. IEA07-04), Montreal: HEC.

Ambec, S. and P. Lanoie (2008), "Does it pay to be green? A systematic overview", Academy of Management Perspectives, 22 (4): 45-62.

Ambec, S., M.A. Cohen, S. Elgie, and P. Lanoie(2013), “The Porter hypothesis at 20: can environmental regulation enhance innovation and competitiveness?", Review of Environmental Economics and Policy, 7 (1): 2-22.

Antweiler, W., and K. Harrison (2003), "Toxic Release Inventories and Green Consumerism: Empirical Evidence from Canada", Canadian Journal of Economics, 36 (2): 495-520.

Arlinghaus, J. (2015), "Impacts of Carbon Prices on Indicators of Competitiveness: A Review of Empirical Findings", OECD Environment Working Papers, No. 87, OECD Publishing, Paris.

Attig, N., S.E. Ghoul, O. Guedhami, J. Suh (2013), “Corporate Social Responsibility and Credit Ratings", Journal of Business Ethics, 117 (4): 679-694.

Ayerbe, C.G. and C.G. Gorriz (2001), "The effects of environmental regulations on the productivity of large companies: an empirical analysis of the Spanish case", Journal of Management and Governance, 5: 129-152.

Blanco, E., J. Rey-Maquieira and J. Lozano (2009), "The Economic Impacts of Voluntary Environmental Performance of Firms: A Critical Review”, Journal of Economic Surveys, 23 (3): 462-502.

Bloom, N., C. Genakos, R. Martin, and R. Sadun (2010), "Modern management: Good for the environment or just hot air?", conomic Journal, 120 (544): 551-572.

Broberg, T., P. Marklund, E. Samakovlis, and H. Hammar, (2013), "Testing the Porter Hypothesis: the effects of environmental investments on efficiency in Swedish industry", Journal of Productivity Analysis, 40 (1): 43-56.

Bushnell, J. B., H. Chong and E.T. Mansur (2013), "Profiting from regulation: Evidence from the European Carbon Market”, American Economic Journal: Economic Policy, 5 (4): 78-106. 
Cheng, B., I. Ioannou, G. Serafeim (2013), "Corporate Social Responsibility and Access to Finance", Strategic”, Management Journal, 35 (1): 1-23.

Cohen, M.A., and A. Tubb, (2017), "The Impact of Environmental Regulation on Firm and Country Competitiveness: A Meta-Analysis of the Porter Hypothesis", Vanderbilt Graduate School of Management Research Paper, No, 2692919.

Crifo, P. and V. D. Forget (2015), "The Economics of Corporate Social Responsibility: A Firm-Level Perspective Survey", Journal of Economic Surveys, https://doi: 10.1111/joes.12055.

Darnall, N. (2009), "Regulatory Stringency, green production offsets, and organizations' financial performance", Public Administration Review, 69: 418-434.

Delmas, M. A. and S. Pekovic (2013), "Environmental standards and labour productivity: Understanding the mechanisms that sustain sustainability", Journal of Organizational Behavior, 34: 230-252.

El Ghoul, S., O. Guedhami, C.C.Y. Kwok and D.R.Mishra (2011), "Does corporate social responsibility affect the cost of capital?", Journal of Banking \& Finance, 35 (9): 2388-2406.

Endrikat, J., E. Guenther, and H. Hoppe (2014), "Making sense of conflicting empirical findings: A metaanalytic review of the relationship between corporate environmental and financial performance", European Management Journal, Vol. 32, pp. 735-751.

Friede, G., T. Busch and A. Bassen (2015), "ESG and financial performance: aggregated evidence from more than 2000 empirical studies", Journal of Sustainable Finance \& Investment, 5(4): 210-233.

Fujii, H., K. Iwata, S. Kaneko, and S. Managi (2013), "Corporate Environmental and Economic Performance of Japanese Manufacturing Firms: Empirical Study for Sustainable Development". Business Strategy and the Environment, 22: 187-201. https://doi: 10.1002/bse.1747.

Goss, A. and G.S. Roberts (2011), "The Impact of Corporate Social Responsibility on the Cost of Bank Loans”, Journal of Banking \& Finance, 35 (7): 1794-1810.

Gosnell, G., J. List and R. Metcalfe (2017), "A new approach to an age-old problem: solving externalities by incenting workers directly", Working Paper, No. 262, Grantham Research Institute on Climate Change and the Environment.Gray, W.B., and R.J. Shadbegian, (2003), "Plant vintage, technology, and environmental regulation", Journal of Environmental Economics and Management, Vol. 46(3), pp. 384-402. Greenstone, M. and T. Gayer (2009), "Quasi-Experimental and Experimental Approaches to Environmental Economics," Journal of Environmental Economics and Management, 57 (1): 21-44.

Gray, W.B. and R.J. Shadbegian (2003), "Plant vintage, technology, and environmental regulation", Journal of Environmental Economics and Management, 46(3): 384-402.

Grolleau, G., N. Mzoughi and S. Pekovic (2012), "Green not (only) for profit: An empirical examination of the effect of environmental-related standards on employees' recruitment", Resource and Energy Economics, 34: 74-92.

Hibiki, A., M. Higashi and A. Matsuda (2003), "Determinants of the Firm to Acquire ISO14001 Certificate and Market Valuation of the Certified Firm", Discussion Paper, $\mathrm{N}^{\circ}$ 03-06, Department of Social Engineering, Tokyo Institute of Technology, Tokyo. 
Horbach, J. (2010), "The Impact of Innovations Activities on Employment in the Environmental Sector Empirical Results for Germany at the Firm Level", Journal of Economics and Statistics, 230 (4): 403-419.

Horbach, J. and K. Rennings (2013), "Environmental Innovation and Employment Dynamics in Different Technology Fields - An Analysis Based on the German Community Innovation Survey 2009", in Journal of Cleaner Production, 57: 158-165.

Horváthová, E. (2010), "Does Environmental Performance Affect Financial Performance? A MetaAnalysis", Ecological Economics, 70 (1): 52-59.

Horváthová, E. (2012), “The impact of environmental performance on firm performance: short-term costs and long-term benefits?", Ecological Economics, 84: 91-97.

Iraldo, F., F. Testa, M. Melis, and M. Frey, (2011), "A Literature Review on the Links between Environmental Regulation and Competitiveness", Environmental Policy and Governance, 21: 210222.

Jacobs, B.W., R. S. Vinod and R. Subramanian (2010), "An empirical investigation of environmental performance and the market value of the firm", Journal of Operations Management, 28 (5): 430441, ISSN 0272-6963.

Jaffe, A. B., S.R. Peterson, P.R. Portney, and R.N. Stavins (1995), "Environmental Regulation and the Competitiveness of U.S. Manufacturing: What Does the Evidence Tell Us?", Journal of Economic Literature, 33 (1): 132-163.

Jaffe, A.B., and K. Palmer (1997), "Environmental Regulation and Innovation: A Panel Data Study", The Review of Economics and Statistics, 79 (4): 610-619.

Jaraite, J. and C. Di Maria (2016), "Did the EU ETS Make a Difference? An Empirical Assessment Using Lithuanian Firm-Level Data", The Energy Journal, 37 (1): 1-23.

Khanna, D. and L.A. Damon (1999), "EPA's Voluntary 33/50 Program: Impact on Toxic Releases and Economic Performance of Firms", Journal of Environmental Economics and Management, Volume 37, Issue 1, 1999, Pages 1-25, ISSN 0095-0696, http://dx.doi.org/10.1006/jeem.1998.1057.

King, A.A. and M.J. Lenox (2001), "Does it really pay to be green? An empirical study of firm environmental and financial performance", Journal of Industrial Ecology, 5 (1): 105-116.

Konar, S. and M. A. Cohen (2001), "Does the market value environmental performance?", Review of economics and statistics, 83 (2): 281-289.

Klemetsen, M. E., K. E. Rosendahl and A. L. Jakobsen (2016), "The impacts of the EU ETS on Norwegian plants' environmental and economic performance", NMBU Working Papers, 3/2016.

Kumar, S. and S. Managi, (2010), "Sulfur dioxide allowances: Trading and technological progress", Ecological Economics, 69: 623-631.

Lankoski, L., 2010: Linkages between Environmental Policy and Competitiveness, OECD Environment Working Papers, No. 13. OECD Publishing, Paris. 
Lanfranchi, L. and S. Pekovic (2012), "How Green is My Firm? Workers' Attitudes towards Job, Job Involvement and Effort in Environmentally-Related Firms", Working Paper, $\mathrm{N}^{\circ}$ 160, Center for Employment Studies.

Lanoie, P., J. Laurent-Lucchetti, N. Johnstone, and S. Ambec (2011), "Environmental policy, Innovation and Performance: New Insights on the Porter Hypothesis", Journal of Economics \& Management Strategy, 20 (3): 803-842.

Levinson, A. and M. Taylor (2008), "Unmasking the pollution haven effect", International Economic Review, 49 (1): 223-254.

List, J. A. D.L. Millimet, P.G. Frederiksson, W.W. McHone (2003), "Effects of Environmental Regulations on Manufacturing Plant Births: Evidence from a Propensity Score Matching Estimator", Review of Economics and Statistics, 85: 944-952.

Marin, G. and F. Vona (2017), "The Impact of Energy Prices on Employment and Environmental Performance: Evidence from French Manufacturing Establishments", SEEDS Working Paper Series, 07/2017.

Martin, R., M. Muûls and L. de Preux (2012), "Anatomy of a Paradox: Management Practices, Organizational Structure and Energy Efficiency", Journal of Environmental Economics and Management, 63 (2): 208-223.

Martin, R., L. B. de Preux and U. J. Wagner (2014a), "The impact of a carbon tax on manufacturing: Evidence from microdata", Journal of Public Economics, 117: 1-14.

Martin, R., M.Muuls, L.B. de Preux, and U.J. Wagner (2014b): "Industry Compensation under Relocation Risk: A Firm-Level Analysis of the EU Emissions Trading Scheme", American Economic Review, 104: $1-24$.

Martin, R., M. Muûls and U. J. Wagner (2016), "The Impact of the European Union Emissions Trading Scheme on Regulated Firms: What Is the Evidence after Ten Years?", Review of Environmental Economics and Policy, 10 (1): 129-148. https://doi: 10.1093/reep/rev016

Mohr, R. D. (2002), "Technical Change, External Economies, and the Porter Hypothesis", Journal of Environmental Economics and Management, 43 (1): 158168.

Morgenstern, R., D., W.A. Pizer, and J.S. Shih (2002), “Jobs versus the environment: An industry-level perspective", Journal of Environmental Economics and Management, 43 (3): 412-436.

Nyborg, K. and T. Zhang (2013), "Is corporate social responsibility associated with lower wages?", Environmental and Resource Economics, 55(1): 107-117. https://doi:10.1007/s10640-012-9617-8.

Oestreich, M. and I. Tsiakas (2015), "Carbon emissions and stock returns: Evidence from the EU Emissions Trading Scheme", Journal of Banking \& Finance, 58: 294-308, ISSN 0378-4266, https://doi.org/10.1016/j.jbankfin.2015.05.005.

Palmer, M. and Y. Truong (2017), "The Impact of Technological Green New. Product Introductions on Firm Profitability", Ecological Economics, 136: 86-93. 
Petrick, S. and U. J. Wagner (2014), "The impact of carbon trading on industry: Evidence from German manufacturing (RMS)", Kiel Working Paper, No. 1912, Kiel, Germany.

Pfeiffer, F. and K. Rennings (2001), "Employment Impacts of Cleaner Production - Evidence from a German Study Using Case Studies and Surveys", Business Strategy and the Environment, 10 (3): $161-175$.

Porter, M. E. and C. van der Linde (1995), "Toward a New Conception of the EnvironmentCompetitiveness Relationship", Journal of Economic Perspectives, 9 (4), 97-118.

Rassier, D.G., and D. Earnhart (2010a), "The Effect of Clean Water Regulation on Profitability: Testing the Porter Hypothesis", Land Economics, 86: 329-344.

Rassier, D.G., and D. Earnhart (2010b), "Does the Porter Hypothesis Explain Expected Future Financial Performance? The effect of clean water regulation on chemical manufacturing firms," Environmental and Resource Economics, 45 (3): 353-377.

Rassier, D.G.and D. Earnhart (2011), "Short-run and long-run implications of environmental regulation on financial performance", Contemporary Economic Policy, 29 (3): 357-373.

Rassier, D.G., and D. Earnhart (2015), "Effects of Environmental Regulation on Actual and Expected Profitability", Ecological Economics, Vol. 112, pp. 129-140. Rennings, K. (2000), "Redefining Innovation - Eco-Innovation Research and the Contribution from Ecological Economics", Ecological Economics, 32: 319-332.

Rennings, K. and T. Zwick (2002), "The Employment Impact of Cleaner Production on the Firm Level Empirical Evidence from a Survey in Five European Countries", International Journal of Innovation Management (IJIM), Special Issue on "The Management of Innovation for Environmental Sustainability", 6 (3): 319-342.

Rennings, K., A. Ziegler and T. Zwick (2004), "The Effect of Environmental Innovations on Employment Changes: An Econometric Analysis”, Business Strategy and the Environment, 13: 374-387.

Rexhäuser, S. and C. Rammer (2014), "Environmental Innovations and Firm Profitability: Unmasking the Porter Hypothesis", Environmental and Resource Economics, 57 (1): 145-167.

Rose, A. (1983), "Modeling the Macroeconomic Impact of Air Pollution Abatement", Journal of Regulatory Science, 23 (4): 441-459.

Sanchez-Vargas, A., R. Mansilla-Sanchez and A. Aguilar-Ibarra, (2013), "An Empirical Analysis of the nonlinear relationship between environmental regulation and manufacturing productivity", Journal of Applied Economics, 16 (2): 357-372.

Shadbegian, R.J. and W.B. Gray (2003), "What determines environmental performance at paper mills? The roles of abatement spending, regulation, and efficiency", topics in The B.E. Economic Analysis \& Policy 3(1). https://doi.org/10.2202/1538-0653.1144

Shadbegian, R. and W. Gray (2005), "Pollution abatement expenditures and plant-level productivity: A production function approach", Ecological Economoics, 54: 196-208. 
Shadbegian, R. and W. Gray (2006), "Assessing multi-dimensional performance: environmental and economic outcomes", Journal of Productivity Analysis, 26 (3): 213-234.

Schmalensee, R. (1993), "The Costs of Environmental Protection", in Balancing Economic Growth and Environmental Goods, pp. 53-80, Washington, DC: American Council for Capital Formation.

Trumpp, C. and T. Guenther (2017), “Too little or too much? Exploring U-shaped relationships between Corporate Environmental Performance and Corporate Financial Performance, Business Strategy and the Environment, Vol. 26, pp. 49-68.

Van Leeuwen, G. and P. Mohnen (2017), "Revisiting the Porter Hypothesis: An empirical analysis of Green Innovation for the Netherlands", Economics of Innovation and New Technology, Vol. 26(12), pp. 63-77.

Veith, S., J.R. Werner and J. Zimmermann (2009), "Capital market response to emission rights returns: Evidence from the European power sector”, Energy Economics, 31 (4): 605- 613.

Wagner, M. (2001), A Review of Empirical Studies Concerning the Relationship Between Environmental and Economic Performance. What does the Evidence Tell us?, Lüneburg: Center for Sustainability Management (electronic version). Available at http://www.sussex.ac.uk/Units/spru/mepi/outputs/Wagner.PDF.

Wagner, M. and J. Blom (2011), "The reciprocal and non-linear relationship of sustainability and financial performance", Business Ethics: A European Review, Vol. 20 (4).

Wagner, U. J., M. Muuls, R. Martin, and J. Colmer (2014), The causal effects of the European Union Emissions Trading Scheme: Evidence from French manufacturing plants. Working Paper. Available at: http://conference.iza.org/conference files/EnvEmpl2014/martin_r7617.pdf.

Walley, N. and B. Whitehead (1994), "It's not easy being green”, Harvard Business Review, May-June: $46-52$. 


\section{Annex A. Summary Table of Empirical Literature}

Papers reviewed in section 2.1: Environmental Performance and economic performance: evidence from stock returns

\begin{tabular}{|c|c|c|c|c|c|c|}
\hline Albertini, 2013 & $\begin{array}{l}\text { Corporate } \\
\text { Environmental } \\
\text { Management (meta- } \\
\text { analysis including } \\
\text { pollution control, } \\
\text { pollution prevention, } \\
\text { product stewardship). }\end{array}$ & $\begin{array}{l}\text { Firm profitability } \\
\text { (meta-analysis). }\end{array}$ & Meta-analysis of 52 studies. & $\begin{array}{l}\text { Meta-analysis } \\
\text { covering studies } \\
\text { between } 1975 \text { and } \\
2011 .\end{array}$ & Correlation & $\begin{array}{l}\text { The meta analysis finds a } \\
\text { positive correlation between } \\
\text { Corporate Environmental } \\
\text { Performance and Corporate } \\
\text { Financial Performance. }\end{array}$ \\
\hline $\begin{array}{l}\text { Al-Tuwaijri et al., } \\
2014\end{array}$ & $\begin{array}{l}\text { Ratio of toxic waste } \\
\text { recycled to total toxic } \\
\text { waste generated. }\end{array}$ & $\begin{array}{l}\text { Industry-adjusted } \\
\text { annual return } \\
\text { (expressing the } \\
\text { firm's current- } \\
\text { period economic } \\
\text { performance } \\
\text { relative to other } \\
\text { firms in the same } \\
\text { industry). }\end{array}$ & $\begin{array}{l}198 \text { US firms. } \\
\text { IRRC Environmental } \\
\text { Profiles database provided } \\
\text { by the US EPA (accessed } \\
\text { through Freedom of } \\
\text { Information Act requests), } \\
\text { Compustat for financial data, } \\
\text { LexisNexis for annual } \\
\text { reports. }\end{array}$ & $\begin{array}{l}\text { Cross-section (year } \\
\text { 1994). }\end{array}$ & Correlation & $\begin{array}{l}\text { Better environmental } \\
\text { performance is significantly } \\
\text { associated with better } \\
\text { economic performance } \\
\text { (significant only at the } 10 \% \\
\text { level). }\end{array}$ \\
\hline Bushnell et al., 2013 & $\begin{array}{l}\text { EU ETS carbon } \\
\text { emissions price. }\end{array}$ & Stock prices. & $\begin{array}{l}552 \text { firms traded on } \\
\text { EUROSTOXX. }\end{array}$ & $\begin{array}{l}\text { Panel (2005-2007; } \\
\text { event study of } \\
\text { price drop in April } \\
\text { 2006). }\end{array}$ & Correlation & $\begin{array}{l}\text { The fall of the permit price in } \\
\text { April } 2006 \text { led to a drop in } \\
\text { stock prices of companies in } \\
\text { carbon- and electricity- }\end{array}$ \\
\hline
\end{tabular}




\begin{tabular}{|c|c|c|c|c|c|c|}
\hline & & & $\begin{array}{l}\text { EU's CITL database, Carbon } \\
\text { Monitoring for Action } \\
\text { Project (CARMA) published } \\
\text { by the Center for Global } \\
\text { Development. }\end{array}$ & & & $\begin{array}{l}\text { intensive industries. Share } \\
\text { prices of firms from the most } \\
\text { carbon-intensive industries } \\
\text { experienced the largest } \\
\text { abnormal declines. }\end{array}$ \\
\hline Darnall, 2009 & $\begin{array}{l}\text { Natural Resource Use, } \\
\text { Solid Waste, Waste- } \\
\text { water effluent, Air } \\
\text { pollution, Greenhouse } \\
\text { Gases, Overall } \\
\text { environmental impact. }\end{array}$ & $\begin{array}{l}\text { Self-reported } \\
\text { profits. }\end{array}$ & $\begin{array}{l}\text { The number of observations } \\
\text { varies across models due to } \\
\text { different response rates for } \\
\text { each environmental } \\
\text { performance variable: } \\
\text { Natural resource use (2609), } \\
\text { Solid Waste (2642), Waste } \\
\text { Water (2386), Air pollution } \\
\text { (2123), GHGs (1723), } \\
\text { Overall environmental } \\
\text { impact (1517). } \\
\text { Survey conducted by the } \\
\text { OECD's Environment } \\
\text { Directorate. }\end{array}$ & $\begin{array}{l}\text { Cross-section } \\
\text { (survey was } \\
\text { conducted in } \\
2003 \text { ). }\end{array}$ & Correlation & $\begin{array}{l}\text { The authors use an OECD } \\
\text { survey across seven countries } \\
\text { to test the effect of regulatory } \\
\text { stringency on firms' profits. } \\
\text { They find that more stringent } \\
\text { environmental policy regimes } \\
\text { are negatively correlated with } \\
\text { facilities' profits. This result } \\
\text { holds for each of the individual } \\
\text { environmental performance } \\
\text { variables. }\end{array}$ \\
\hline Fujii et al., 2013 & $\begin{array}{l}\mathrm{CO} 2 \text { emissions, } \\
\text { chemical emissions } \\
\text { relative to sales. }\end{array}$ & $\begin{array}{l}\text { Return on Assets } \\
\text { (ROA), Return on } \\
\text { Sales (ROS), } \\
\text { Capital Turnover } \\
\text { (CT). }\end{array}$ & $\begin{array}{l}758 \text { Japanese manufacturing } \\
\text { firms for CO2 emissions; } \\
2498 \text { Japanese } \\
\text { manufacturing firms for } \\
\text { toxic chemicals emissions. } \\
\text { GHG emissions from the } \\
\text { mandatory GHG Accounting } \\
\text { and Reporting System of the } \\
\text { Japanese Ministry of } \\
\text { Environment, Pollutant } \\
\text { Release and Transfer } \\
\text { Register (PRTR) from } \\
\text { Ministry of Environment, }\end{array}$ & $\begin{array}{l}\text { Panel; for CO2 } \\
\text { emissions (2006- } \\
\text { 2008); for toxic } \\
\text { chemicals (2001- } \\
\text { 2008). }\end{array}$ & Correlation & $\begin{array}{l}\text { The relationship between } \\
\text { environmental performance } \\
\text { and financial performance } \\
\text { differs across pollutants: } \\
\text { For toxic chemical substances } \\
\text { they find a significant inverted } \\
\text { U-shape relationship between } \\
\text { ROA and environmental } \\
\text { performance. For CO2 } \\
\text { Emissions they find a } \\
\text { significant positive } \\
\text { relationship between ROA, } \\
\text { ROS and environmental } \\
\text { performance. They find no }\end{array}$ \\
\hline
\end{tabular}




\begin{tabular}{|c|c|c|c|c|c|c|}
\hline & & & $\begin{array}{l}\text { financial data from Nikkei } \\
\text { Economic Electronic } \\
\text { database system. }\end{array}$ & & & $\begin{array}{l}\text { significant relationship with } \\
\text { CT. }\end{array}$ \\
\hline Hibiki et al., 2003 & $\begin{array}{l}\text { ISO14001 } \\
\text { certification. }\end{array}$ & $\begin{array}{l}\text { Stock returns; } \\
\text { Tobin's Q (market } \\
\text { value of the firm). }\end{array}$ & $\begin{array}{l}573 \text { publicly-held firms in } \\
\text { the manufacturing industry } \\
\text { listed at the Tokyo Stock } \\
\text { Exchange. }\end{array}$ & $\begin{array}{l}\text { Cross-section (year } \\
\text { 2002). }\end{array}$ & Correlation & $\begin{array}{l}\text { The authors find that the } \\
\text { voluntary introduction of the } \\
\text { ISO } 14001 \text { certification } \\
\text { contributes to a statistically } \\
\text { significant increase in the } \\
\text { market value of the firm by } \\
11 \% \text { to } 14 \% \text {. The authors } \\
\text { explain this finding with two } \\
\text { possible effects: the expected } \\
\text { reduction in the potential risk } \\
\text { of environmental liabilities, } \\
\text { and the lower adjustment cost } \\
\text { if environmental policy is } \\
\text { tightened in the future. }\end{array}$ \\
\hline Horvathova, 2010 & $\begin{array}{l}\text { Environmental } \\
\text { performance (meta- } \\
\text { analysis). }\end{array}$ & $\begin{array}{l}\text { Financial } \\
\text { performance } \\
\text { (meta-analysis). }\end{array}$ & $\begin{array}{l}\text { Meta-analysis of } 64 \\
\text { outcomes from } 37 \text { empirical } \\
\text { studies. Literature search } \\
\text { was conducted in } \\
2008 / 2009 \text {. }\end{array}$ & $\mathrm{N} / \mathrm{A}$ & Correlation & $\begin{array}{l}\text { The results suggest both that } \\
\text { the empirical method matters } \\
\text { for the findings and that the } \\
\text { likelihood of finding a } \\
\text { negative link between } \\
\text { environmental and financial } \\
\text { performance significantly } \\
\text { increases when using simple } \\
\text { correlation coefficients instead } \\
\text { of more advanced econometric } \\
\text { analysis. The results also } \\
\text { indicate that the portfolio } \\
\text { studies tend to report a } \\
\text { negative link between } \\
\text { environmental and financial } \\
\text { performance. This likely }\end{array}$ \\
\hline
\end{tabular}




\begin{tabular}{|c|c|c|c|c|c|c|}
\hline & & & & & & $\begin{array}{l}\text { reflects the omitted factors in } \\
\text { portfolio studies. The positive } \\
\text { link is found more frequently } \\
\text { in common law countries than } \\
\text { in civil law countries. The } \\
\text { results also suggest that } \\
\text { appropriate time coverage is } \\
\text { important in order to establish } \\
\text { a positive link between EP and } \\
\text { FP. This suggests that it takes } \\
\text { time for environmental } \\
\text { regulation to materialise in } \\
\text { financial performance. }\end{array}$ \\
\hline Horvathova, 2012 & $\begin{array}{l}\text { Composite indicator } \\
\text { on } 93 \text { pollutants (air, } \\
\text { water, land, off-site } \\
\text { transfers of waste, } \\
\text { pollutants in waste } \\
\text { water from industrial } \\
\text { facilities). }\end{array}$ & $\begin{array}{l}\text { Return on Assets } \\
\text { (ROA), Return on } \\
\text { Equity (ROE). }\end{array}$ & $\begin{array}{l}\text { 136 Czech firms. } \\
\text { Environmental performance } \\
\text { data from integrated register } \\
\text { of pollutant emissions, } \\
\text { which is part of the } \\
\text { European Pollutant Release } \\
\text { and Transfer register } \\
\text { (EPRT) (publicly available), } \\
\text { data on environmental } \\
\text { managerial systems are } \\
\text { collected using publicly } \\
\text { available database } \\
\text { (www.iso.cz) and double- } \\
\text { checking the websites of } \\
\text { companies, financial data are } \\
\text { obtained from a commercial } \\
\text { firm database CreditInfo. }\end{array}$ & Panel (2004-2008). & Correlation & $\begin{array}{l}\text { Better environmental } \\
\text { performance decreases } \\
\text { financial performance in the } \\
\text { following year, but increases } \\
\text { financial performance after } \\
\text { two years. }\end{array}$ \\
\hline
\end{tabular}




\begin{tabular}{|c|c|c|c|c|c|c|}
\hline Jacobs et al., 2010 & $\begin{array}{l}\text { Corporate } \\
\text { Environment } \\
\text { Initiatives (CEI) } \\
\text { announcements, } \\
\text { which are self- } \\
\text { reported corporate } \\
\text { efforts to avoid, } \\
\text { mitigate or offset the } \\
\text { firm's environmental } \\
\text { impact. } \\
\text { Environmental } \\
\text { Awards and } \\
\text { Certification (EAC) } \\
\text { announcements, } \\
\text { which are awards } \\
\text { granted by third } \\
\text { parties. EAC } \\
\text { announcements } \\
\text { include ISO 14001 } \\
\text { and LEED } \\
\text { certification, as well } \\
\text { as federal, state or } \\
\text { local environmental } \\
\text { awards. }\end{array}$ & $\begin{array}{l}\text { Abnormal returns } \\
\text { on stock prices. }\end{array}$ & $\begin{array}{l}340 \text { firms across } 63 \text { three- } \\
\text { digit NAICS codes, with a } \\
\text { total of } 780 \text { announcements; } \\
417 \text { Corporate Environment } \\
\text { Initiatives (CEI), } 363 \\
\text { Environmental Awards and } \\
\text { Certification (EAC). } \\
\text { Dataset created by authors } \\
\text { through monitoring business } \\
\text { announcements in } \\
\text { newspapers. }\end{array}$ & $\begin{array}{l}\text { Panel; event study } \\
\text { over a 200-day } \\
\text { period, which is } \\
\text { specific for each } \\
\text { firm's } \\
\text { announcement. }\end{array}$ & Correlation & $\begin{array}{l}\text { The authors examine the stock } \\
\text { market reaction associated } \\
\text { with announcements of } \\
\text { environmental performance. } \\
\text { They find no significant effect } \\
\text { for the aggregated sample of } \\
\text { CEI and EAC announcements. } \\
\text { Yet, they observe significant } \\
\text { effects for sub-groups of the } \\
\text { announcements. } \\
\text { Announcements of } \\
\text { philanthropic gifts for } \\
\text { environmental causes and ISO } \\
\text { 14001 are associated with a } \\
\text { significant positive market } \\
\text { reaction. Voluntary emissions } \\
\text { reductions are associated with } \\
\text { significant negative market } \\
\text { reactions. }\end{array}$ \\
\hline $\begin{array}{l}\text { Khanna and Damon, } \\
1999\end{array}$ & $\begin{array}{l}\text { Toxic releases of } 17 \\
\text { high priority toxic } \\
\text { chemicals regulated } \\
\text { under the voluntary } \\
\text { US EPA } 33 / 50 \\
\text { Programme. }\end{array}$ & $\begin{array}{l}\text { Return on } \\
\text { Investment (ROI), } \\
\text { Excess value per } \\
\text { unit sales (EVS). }\end{array}$ & $\begin{array}{l}123 \text { US chemical firms. } \\
\text { S\&P's Compustat database, } \\
\text { CD corporate database, } \\
\text { Toxic Release Inventory. }\end{array}$ & Panel (1991-1993). & Correlation & $\begin{array}{l}\text { Participation in the voluntary } \\
\text { US EPA } 33 / 50 \text { programme led } \\
\text { to a significant decline in toxic } \\
\text { releases relative to non- } \\
\text { participants, after controlling } \\
\text { for sample selection through } \\
\text { firm-specific factors. } \\
\text { Programme participation had a } \\
\text { significant negative effect on } \\
\text { current returns on investment }\end{array}$ \\
\hline
\end{tabular}




\begin{tabular}{|c|c|c|c|c|c|c|}
\hline & & & & & & $\begin{array}{l}\text { (ROI) relative to non- } \\
\text { participants. Yet, it had a } \\
\text { significant positive effect on } \\
\text { the Excess Value per unit } \\
\text { Sales (EVS). This indicates } \\
\text { that investors anticipate that in } \\
\text { the long run the current efforts } \\
\text { to reduce pollution improve } \\
\text { the expected profitability of } \\
\text { firms participating in the } \\
\text { programme. }\end{array}$ \\
\hline King and Lenox, 2001 & $\begin{array}{l}\text { Total Emissions: } \\
\text { Total facility } \\
\text { emissions of toxic } \\
\text { chemicals; Relative } \\
\text { Emissions: Emissions } \\
\text { relative to other } \\
\text { facilities of similar } \\
\text { sector, and size } \\
\text { Industry Emissions: } \\
\text { Emissions per } \\
\text { employee for the } \\
\text { sectors in which the } \\
\text { firm operates. } \\
\end{array}$ & $\begin{array}{l}\text { Tobin's Q } \\
\text { financial } \\
\text { performance } \\
\text { measure (market } \\
\text { valuation of a firm } \\
\text { relative to the } \\
\text { replacement costs } \\
\text { of tangible assets). }\end{array}$ & $\begin{array}{l}652 \text { US manufacturing firms } \\
\text { Toxic Release inventory } \\
\text { (TRI), facility data from } \\
\text { Dun and Bradstreet (D\&B), } \\
\text { corporate data from } \\
\text { Standard \& Poor's } \\
\text { Compustat database. }\end{array}$ & Panel (1987-1996). & Correlation & $\begin{array}{l}\text { The authors identify three key } \\
\text { results: 1) Higher total } \\
\text { emissions are associated with } \\
\text { lower financial performance. } \\
\text { 2) Firms with higher relative } \\
\text { emissions compared to firms } \\
\text { of similar sector and size have } \\
\text { lower financial performance. } \\
\text { 3) No effect for Industry } \\
\text { Emissions: Operating in a } \\
\text { cleaner industry does not have } \\
\text { an effect per se on financial } \\
\text { performance. }\end{array}$ \\
\hline $\begin{array}{l}\text { Konar and Cohen, } \\
2001\end{array}$ & $\begin{array}{l}\text { The aggregate pounds } \\
\text { of toxic chemicals } \\
\text { emitted per dollar } \\
\text { revenue; The number } \\
\text { of environmental } \\
\text { lawsuits pending } \\
\text { against the firm in } \\
1989 .\end{array}$ & $\begin{array}{l}\text { Intangible-asset } \\
\text { value (market } \\
\text { value). }\end{array}$ & $\begin{array}{l}321 \text { mostly manufacturing } \\
\text { firms in the S\&P 500; } \\
\text { Financial performance data } \\
\text { taken from Compustat, } \\
\text { market share and } \\
\text { concentration data from } \\
\text { Ward's Business Directory, } \\
\text { R\&D expenditures using } \\
\text { data from the Disclosure }\end{array}$ & $\begin{array}{l}\text { Cross-section (year } \\
\text { 1989). }\end{array}$ & Correlation & $\begin{array}{l}\text { The authors observe that bad } \\
\text { environmental performance is } \\
\text { negatively correlated with the } \\
\text { intangible asset value of firms. } \\
\text { They find that a } 10 \% \text { reduction } \\
\text { in emissions of toxic } \\
\text { chemicals results in a US } \$ 34 \\
\text { million increase in market } \\
\text { value. Their evidence suggests }\end{array}$ \\
\hline
\end{tabular}




\begin{tabular}{|c|c|c|c|c|c|c|}
\hline & & & $\begin{array}{l}\text { database, advertising } \\
\text { expenditures (ADVAL89) } \\
\text { were taken from data } \\
\text { published by the Arbitron } \\
\text { Company, the number of } \\
\text { environmental law suits } \\
\text { pending and toxic emissions } \\
\text { data from Investor } \\
\text { Responsibility Research } \\
\text { Center. }\end{array}$ & & & $\begin{array}{l}\text { that firms are rewarded in the } \\
\text { marketplace for over- } \\
\text { complying with environmental } \\
\text { regulation and for externally } \\
\text { portraying an image of being } \\
\text { environmentally concerned. }\end{array}$ \\
\hline Martin et al., 2014b & $\begin{array}{l}\mathrm{CO} 2 \text { emissions, } \\
\text { management practices } \\
\text { related to climate } \\
\text { policy (interview } \\
\text { data). }\end{array}$ & $\begin{array}{l}\text { Vulnerability to } \\
\text { carbon pricing } \\
\text { (interview data). }\end{array}$ & $\begin{array}{l}761 \text { firms across Belgium, } \\
\text { France, Germany, Hungary, } \\
\text { Poland, UK. } \\
\text { Survey on management } \\
\text { practices conducted by the } \\
\text { authors, ORBIS for } \\
\text { economic performance, EU } \\
\text { CITL for emissions data, } \\
\text { Eurostat. }\end{array}$ & $\begin{array}{l}\text { Cross-section } \\
\text { (Interviews } \\
\text { conducted in } \\
2009 \text { ). }\end{array}$ & Correlation & $\begin{array}{l}\text { The authors propose an } \\
\text { industry compensation scheme } \\
\text { to prevent relocation of firms } \\
\text { as a response to carbon } \\
\text { pricing. It requires that } \\
\text { compensation is distributed } \\
\text { across firms to equalize the } \\
\text { expected marginal impact of } \\
\text { relocation on the regulator. } \\
\text { They show that the existing } \\
\text { free allocation of permits } \\
\text { under the EU ETS results in } \\
\text { substantial overcompensation } \\
\text { of firms. }\end{array}$ \\
\hline $\begin{array}{l}\text { Oestreich and } \\
\text { Tsiakas, } 2015\end{array}$ & $\begin{array}{l}\text { EU ETS carbon } \\
\text { emission allowances. }\end{array}$ & Stock returns. & $\begin{array}{l}65 \text { publicly traded German } \\
\text { firms on the two major } \\
\text { German stock exchanges } \\
\text { (DAX and MDAX). } \\
\text { DataStream for stock returns } \\
\text { (commercial), EU CITL for } \\
\text { emissions (public). }\end{array}$ & $\begin{array}{l}\text { Panel (monthly; } \\
\text { 2003-2012). }\end{array}$ & Correlation & $\begin{array}{l}\text { During the first years of the } \\
\text { EU ETS, firms which received } \\
\text { free carbon emission } \\
\text { allowances significantly } \\
\text { outperformed firms that did } \\
\text { not. Thus, there is a large and } \\
\text { significant carbon premium in } \\
\text { stock returns. Between } 2003 \\
\text { and } 2009 \text { the carbon premium }\end{array}$ \\
\hline
\end{tabular}




\begin{tabular}{|c|c|c|c|c|c|c|}
\hline & & & & & & $\begin{array}{l}\text { can be as high as } 17 \% \text {, yet the } \\
\text { premium dissipates after } 2009 \text {. } \\
\text { It is largely explained by } \\
\text { higher cash flows due to the } \\
\text { free allocation of carbon } \\
\text { emission allowances. }\end{array}$ \\
\hline $\begin{array}{l}\text { Rassier and Earnhart, } \\
\text { 2010a }\end{array}$ & $\begin{array}{l}\text { Permitted wastewater } \\
\text { discharge limits for } \\
\text { BOD (biochemical } \\
\text { oxygen demand) and } \\
\text { TSS (total suspended } \\
\text { solids). }\end{array}$ & $\begin{array}{l}\text { Profitability as } \\
\text { measured by } \\
\text { returns on sales } \\
\text { (ROS). }\end{array}$ & $\begin{array}{l}\text { Publicly held chemical } \\
\text { manufacturing firms. The } \\
\text { sample of annual data } \\
\text { contains } 337 \text { observations, } \\
\text { consisting of } 73 \text { chemical } \\
\text { manufacturing firms. The } \\
\text { sample panel of quarterly } \\
\text { data contains } 926 \\
\text { observations, consisting of } \\
59 \text { chemical manufacturing } \\
\text { firms. } \\
\text { US EPA's Permit } \\
\text { Compliance System (PCS) } \\
\text { database for permitted } \\
\text { discharge limits, S\&P } \\
\text { Compustat for financial data, } \\
\text { PCS database for facility } \\
\text { level environmental data. }\end{array}$ & $\begin{array}{l}\text { Panel (1995- 2001) } \\
\text { yearly data. }\end{array}$ & Correlation & $\begin{array}{l}\text { The authors obtain consistent } \\
\text { results across both of their } \\
\text { samples. A } 10 \% \text { reduction in } \\
\text { the average relative permitted } \\
\text { discharge limit causes the } \\
\text { return on sales to decrease by } \\
\text { as little as } 0.8 \% \text { and as much } \\
\text { as } 2.7 \% \text { according to the } 90 \% \\
\text { confidence interval of the } \\
\text { estimated coefficient on the } \\
\text { discharge limit }\end{array}$ \\
\hline $\begin{array}{l}\text { Rassier and Earnhart, } \\
2010 \mathrm{~b}\end{array}$ & $\begin{array}{l}\text { Permitted wastewater } \\
\text { discharge limits for } \\
\text { BOD (biochemical } \\
\text { oxygen demand) and } \\
\text { TSS (total suspended } \\
\text { solids). }\end{array}$ & $\begin{array}{l}\text { Tobin's Q } \\
\text { financial } \\
\text { performance } \\
\text { measure. }\end{array}$ & $\begin{array}{l}229 \text { observations covering } \\
54 \text { public owned chemical } \\
\text { manufacturing firms. } \\
\text { Environmental Protection } \\
\text { Agency's (EPA's) Permit }\end{array}$ & Panel (1995-2000). & Correlation & $\begin{array}{l}\text { They find a negative } \\
\text { relationship between clean } \\
\text { water regulations and expected } \\
\text { future financial performance. } \\
\text { The more stringent clean water } \\
\text { regulation induces investors to }\end{array}$ \\
\hline
\end{tabular}




\begin{tabular}{|c|c|c|c|c|c|c|}
\hline & & & $\begin{array}{l}\text { Compliance System (PCS) } \\
\text { for permitted limits of } \\
\text { wastewater discharge, } \\
\text { Standard \& Poor's } \\
\text { Compustat Research Insight } \\
\text { for financial data. }\end{array}$ & & & $\begin{array}{l}\text { revise downward their } \\
\text { expectations of future profits. } \\
\text { A } 50 \% \text { decrease in the average } \\
\text { firm's permitted discharge } \\
\text { limit generates a decrease of } \\
1.3 \% \text { or approximately } \$ 310.4 \\
\text { million in the average firm's } \\
\text { market value. }\end{array}$ \\
\hline $\begin{array}{l}\text { Rassier and Earnhart, } \\
2011\end{array}$ & $\begin{array}{l}\text { Permitted wastewater } \\
\text { discharge limits for } \\
\text { BOD (biochemical } \\
\text { oxygen demand) and } \\
\text { TSS (total suspended } \\
\text { solids). }\end{array}$ & Returns on Sales. & $\begin{array}{l}53 \text { US firms belonging to the } \\
\text { chemical manufacturing } \\
\text { industry. } \\
\text { EPA Permit Compliance } \\
\text { System database on } \\
\text { permitted discharge limits, } \\
\text { S\&P Compustat for financial } \\
\text { data. }\end{array}$ & $\begin{array}{l}\text { Panel (quarterly; } \\
1 \text { st quarter of } 1995 \\
\text { to } 2 \text { nd quarter of } \\
2001 ; \text { maximum of } \\
26 \text { observations per } \\
\text { firm). }\end{array}$ & Correlation & $\begin{array}{l}\text { Lower emissions improve firm } \\
\text { financial performance both in } \\
\text { the short and long run, with a } \\
\text { stronger effect in the long run. }\end{array}$ \\
\hline $\begin{array}{l}\text { Rassier and Earnhart, } \\
2015\end{array}$ & $\begin{array}{l}\text { Permitted wastewater } \\
\text { discharge limits for } \\
\text { BOD (biochemical } \\
\text { oxygen demand) and } \\
\text { TSS (total suspended } \\
\text { solids). }\end{array}$ & $\begin{array}{l}\text { Actual } \\
\text { Profitability } \\
\text { (return on sales), } \\
\text { Investors } \\
\text { expectations of } \\
\text { future profitability } \\
\text { measured by } \\
\text { Tobin's q. }\end{array}$ & $\begin{array}{l}740 \text { observations from } 47 \\
\text { firms. } \\
\text { EPA's Permit Compliance } \\
\text { System (PCS) database, } \\
\text { S\&P Compustat for financial } \\
\text { data. }\end{array}$ & $\begin{array}{l}\text { Panel (1995-2001) } \\
\text { quarterly. }\end{array}$ & Correlation & $\begin{array}{l}\text { Their results on actual } \\
\text { profitability are consistent with } \\
\text { the Porter hypothesis } \\
\text { indicating that tighter clean } \\
\text { water regulation is positively } \\
\text { associated with profitability. } \\
\text { However, their results on } \\
\text { expected profitability suggest } \\
\text { that investors appear to expect } \\
\text { a negative relationship } \\
\text { between clean water regulation } \\
\text { and profitability. }\end{array}$ \\
\hline $\begin{array}{l}\text { Trumpp and } \\
\text { Guenther, } 2017\end{array}$ & $\begin{array}{l}\text { Carbon performance } \\
\text { (negative GHG } \\
\text { emissions divided by } \\
\text { sales), Waste intensity } \\
\text { (negative amount of }\end{array}$ & $\begin{array}{l}\text { Profitability } \\
\text { (Return over } \\
\text { assets), stock } \\
\text { market } \\
\text { performance } \\
\text { (annual change in }\end{array}$ & $\begin{array}{l}2361 \text { firm-years. } \\
\text { GHG emissions from } \\
\text { Carbon Disclosure Project } \\
\text { (public), waste intensity and } \\
\text { financial data from Thomson }\end{array}$ & Panel (2008-2012). & correlation & $\begin{array}{l}\text { They find a non-linear U- } \\
\text { shaped relationship between } \\
\text { carbon performance and } \\
\text { profitability, as well as } \\
\text { between waste intensity and } \\
\text { profitability. Thus, within their }\end{array}$ \\
\hline
\end{tabular}


42 ECO/WKP(2018)62

\begin{tabular}{|c|c|c|c|c|c|c|}
\hline & $\begin{array}{l}\text { waste produced by a } \\
\text { firm divided by sales). }\end{array}$ & $\begin{array}{l}\text { stock prices plus } \\
\text { dividends). }\end{array}$ & $\begin{array}{l}\text { Reuter's ASSET4 database } \\
\text { (commercial). }\end{array}$ & & & $\begin{array}{l}\text { sample firms with a low } \\
\text { corporate environmental } \\
\text { performance (CEP) tend to } \\
\text { have a negative relationship } \\
\text { with corporate financial } \\
\text { performance (CFP), whereas } \\
\text { firms at high levels of CEP } \\
\text { have a positive relationship } \\
\text { with CFP. }\end{array}$ \\
\hline Veith et al., 2009 & $\begin{array}{l}\text { EU ETS carbon } \\
\text { emission allowances. }\end{array}$ & Stock returns. & $\begin{array}{l}22 \text { European power } \\
\text { generation companies. } \\
\text { DataStream database. }\end{array}$ & $\begin{array}{l}\text { Panel (daily; 2005- } \\
\text { 2007). }\end{array}$ & Correlation & $\begin{array}{l}\text { The authors find a positive } \\
\text { correlation between carbon } \\
\text { prices and returns on stocks. } \\
\text { This implies that the market } \\
\text { predicts that firms are able to } \\
\text { pass on their share of the } \\
\text { regulatory burden from the EU } \\
\text { ETS and can even achieve } \\
\text { windfall profits. }\end{array}$ \\
\hline $\begin{array}{l}\text { Wagner and Blom, } \\
2011\end{array}$ & $\begin{array}{l}\text { Environmental } \\
\text { Management Systems } \\
\text { (EMS). }\end{array}$ & $\begin{array}{l}\text { Firms' financial } \\
\text { performance } \\
\text { (Return on Sales). }\end{array}$ & $\begin{array}{l}497 \text { firms from Germany } \\
\text { and the UK. } \\
\text { Survey conducted by authors } \\
\text { on EMS system, financial } \\
\text { data from AMADEUS } \\
\text { database. }\end{array}$ & $\begin{array}{l}\text { Cross-section } \\
\text { ( survey conducted } \\
\text { in 2001). }\end{array}$ & Correlation & $\begin{array}{l}\text { The authors use the } \\
\text { implementation of an } \\
\text { Environmental Management } \\
\text { System (EMS) for firms' level } \\
\text { of sustainability. They find a } \\
\text { positive association between } \\
\text { the implementation of an EMS } \\
\text { and financial performance for } \\
\text { already well-performing firms } \\
\text { only. For less well-performing } \\
\text { firms they find a negative } \\
\text { relationship between EMS } \\
\text { implementation and financial } \\
\text { performance. They find no } \\
\text { effect for their pooled dataset. }\end{array}$ \\
\hline
\end{tabular}




\begin{tabular}{|l|l|l|l|l|l|}
\hline Wagner, 2001 & Review study. & NA & NA & NA & $\begin{array}{l}\text { Evidence from early studies } \\
\text { indicates no significant } \\
\text { relationship between } \\
\text { environmental and economic } \\
\text { performance, the more recent } \\
\text { studies carried out on the } \\
\text { relationship between the two } \\
\text { indicate that a significant } \\
\text { relationship exists between } \\
\text { environmental and economic } \\
\text { performance, but they give no } \\
\text { clear indication about whether } \\
\text { this is positive or negative. }\end{array}$ \\
\hline
\end{tabular}

Papers reviewed in section 2.2: Understanding the drivers: why environmental performance can go hand in hand with economic performance

\begin{tabular}{|c|c|c|c|c|c|c|}
\hline $\begin{array}{l}\text { Antweiler and } \\
\text { Harrison, } 2003\end{array}$ & $\begin{array}{l}192 \text { toxic air, water, } \\
\text { land, and subsoil } \\
\text { pollutants covered in } \\
\text { Canada's National } \\
\text { Pollutant Release } \\
\text { Inventory (NPRI). }\end{array}$ & $\begin{array}{l}\text { Consumer market } \\
\text { exposure. }\end{array}$ & $\begin{array}{l}2500 \text { Canadian facilities, } \\
\text { which report emissions } \\
\text { under Canada's NPRI. } \\
\text { Canada's National Pollutant } \\
\text { Release Inventory (NPRI) } \\
\text { (publicly accessible through } \\
\text { website), Canadian Census } \\
\text { for facility location (public), } \\
\text { Statistics Canada (public). }\end{array}$ & Panel (1993-1999). & Correlation & $\begin{array}{l}\text { Companies that are relatively } \\
\text { more exposed to final } \\
\text { consumers and that have a } \\
\text { greater diversity of emissions } \\
\text { across products (i.e. are more } \\
\text { "environmentally-leveraged") } \\
\text { reduce their releases to air and } \\
\text { transfers of wastes off site } \\
\text { most strongly. Yet, they also } \\
\text { increase more the less visible } \\
\text { releases of subsoil emissions. } \\
\text { They argue that this indicates } \\
\text { the existence of a "green } \\
\text { consumerism", although its } \\
\text { overall environmental impact } \\
\text { is small. }\end{array}$ \\
\hline
\end{tabular}




\begin{tabular}{|c|c|c|c|c|c|c|}
\hline Horbach, 2010 & $\begin{array}{l}\text { Environmental } \\
\text { product innovations. }\end{array}$ & $\begin{array}{l}\text { Employment at } \\
\text { the firm level. }\end{array}$ & $\begin{array}{l}900 \text { German firms operating } \\
\text { in environmental sectors; } \\
12.400 \text { German firms } \\
\text { operating in non- } \\
\text { environmental fields. } \\
\text { Establishment panel of the } \\
\text { Institute for Employment } \\
\text { Research Nuremberg. }\end{array}$ & Panel (2002-2005). & Correlation & $\begin{array}{l}\text { Firms in the environmental } \\
\text { sector that developed new or } \\
\text { modified products from } 2002 \\
\text { to } 2003 \text { increased their } \\
\text { employment from } 2003 \text { to } \\
\text { 2005. The employment impact } \\
\text { of innovation is larger than for } \\
\text { firms in non-environmental } \\
\text { sectors. }\end{array}$ \\
\hline $\begin{array}{l}\text { Palmer and Truong, } \\
2017\end{array}$ & $\begin{array}{l}\text { Technological green } \\
\text { product introductions } \\
(\mathrm{NPI}) \text {. }\end{array}$ & $\begin{array}{l}\text { Firm profitability } \\
\text { measured by } \\
\text { turnover and } \\
\text { return on capital. }\end{array}$ & $\begin{array}{l}79 \text { global firms ( } 1020 \\
\text { technological green product } \\
\text { introductions. } \\
\text { Authors constructed the } \\
\text { dataset of NPIs based on } \\
\text { press releases. }\end{array}$ & Panel (2007-2012). & Correlation & $\begin{array}{l}\text { They find a significant positive } \\
\text { correlation between } \\
\text { technology-based green new } \\
\text { product introductions (NPI) } \\
\text { and short term profitability } \\
\text { measured by turnover or return } \\
\text { on capital. They also find a } \\
\text { weakly significant relationship } \\
\text { when using the ratio of } \\
\text { technological green NPIs to } \\
\text { the total number of NPIs. This } \\
\text { finding might suggest that a } \\
\text { higher share of green products } \\
\text { is associated with extra } \\
\text { profitability. }\end{array}$ \\
\hline $\begin{array}{l}\text { Rennings and Zwick, } \\
2002\end{array}$ & $\begin{array}{l}\text { Introduction of new } \\
\text { environmental } \\
\text { products; } \\
\text { environmental } \\
\text { innovations. }\end{array}$ & $\begin{array}{l}\text { Employment at } \\
\text { the firm level. }\end{array}$ & $\begin{array}{l}1594 \text { interviews of } \\
\text { environmentally innovative } \\
\text { industry and services firms } \\
\text { from Germany, Italy, } \\
\text { Switzerland, UK, and } \\
\text { Netherlands. The firms span } \\
\text { across } 8 \text { NACE sectors (D- } \\
\text { K). Firms were only }\end{array}$ & $\begin{array}{l}\text { Cross-section } \\
\text { (interviews were } \\
\text { carried out in } \\
\text { 2000). }\end{array}$ & Correlation & $\begin{array}{l}\text { Environmental innovations } \\
\text { have a small but positive effect } \\
\text { on employment at the firm } \\
\text { level. Product and service } \\
\text { innovation generate more jobs } \\
\text { than process innovations. } \\
\text { Employment impacts differ } \\
\text { according to the intended goals }\end{array}$ \\
\hline
\end{tabular}




\begin{tabular}{|c|c|c|c|c|c|c|}
\hline & & & $\begin{array}{l}\text { included if they self-reported } \\
\text { to have done at least one } \\
\text { environmental innovation in } \\
\text { the past three years. } \\
\text { Survey conducted by } \\
\text { authors. }\end{array}$ & & & $\begin{array}{l}\text { of the innovation: If they are } \\
\text { motivated by cost reduction, } \\
\text { they tend to reduce } \\
\text { employment. If they are } \\
\text { motivated by goals to increase } \\
\text { the market share, the effect can } \\
\text { be positive or negative. }\end{array}$ \\
\hline Rennings et al., 2004 & $\begin{array}{l}\text { Environmental } \\
\text { Innovations. }\end{array}$ & $\begin{array}{l}\text { Employment at } \\
\text { the firm level. }\end{array}$ & $\begin{array}{l}1594 \text { interviews of } \\
\text { environmentally innovative } \\
\text { industry and services firms } \\
\text { from Germany, Italy, } \\
\text { Switzerland, UK, and } \\
\text { Netherlands. The firms span } \\
\text { across } 8 \text { NACE sectors (D- } \\
\text { K). Firms were only } \\
\text { included if they self-reported } \\
\text { to have done at least one } \\
\text { environmental innovation in } \\
\text { the past three years. } \\
\text { Survey conducted by } \\
\text { authors. }\end{array}$ & $\begin{array}{l}\text { Cross-section } \\
\text { (interviews were } \\
\text { carried out in } \\
2000 \text { ). }\end{array}$ & Correlation & $\begin{array}{l}\text { Environmental product and } \\
\text { service innovations increase } \\
\text { the likelihood that the firm } \\
\text { increases its employment base. } \\
\text { Yet environmental end-of-pipe } \\
\text { innovations increase the } \\
\text { likelihood that the firm } \\
\text { decreases its employment } \\
\text { base. }\end{array}$ \\
\hline $\begin{array}{l}\text { Ayerbe and Gorriz, } \\
2001\end{array}$ & $\begin{array}{l}\text { Firm-specific costs of } \\
\text { executing individual } \\
\text { environmental project } \\
\text { (i.e. firm-specific } \\
\text { pollution abatement } \\
\text { cost). }\end{array}$ & $\begin{array}{l}\text { Work productivity } \\
\text { (measured as } \\
\text { value-added per } \\
\text { worker). }\end{array}$ & $\begin{array}{l}53 \text { large Spanish companies, } \\
\text { quoted on the stock market. } \\
\text { Data on participation in the } \\
\text { PITMA programme is } \\
\text { publicly available through } \\
\text { the Official State Gazette } \\
\text { from the Department of } \\
\text { Industry and Energy } \\
\text { (MINER). Balance Sheet } \\
\text { and Income Statement } \\
\text { information are obtained }\end{array}$ & Panel (1990-1995). & Correlation & $\begin{array}{l}\text { The authors study the effect of } \\
\text { participation in the Spanish } \\
\text { Industrial and Technological } \\
\text { Programme for the } \\
\text { Environment (PITMA), a } \\
\text { subsidized pollution abatement } \\
\text { programme. They find a small } \\
\text { negative association between } \\
\text { work productivity and } \\
\text { pollution abatement } \\
\text { investment dedicated to } \\
\text { compliance with the pollution }\end{array}$ \\
\hline
\end{tabular}




\begin{tabular}{|c|c|c|c|c|c|c|}
\hline & & & $\begin{array}{l}\text { from the National Securities } \\
\text { Market Commission } \\
\text { (CNMV), which is available } \\
\text { for publicly listed } \\
\text { companies. }\end{array}$ & & & $\begin{array}{l}\text { standard. They argue that this } \\
\text { result is specific to the } \\
\text { command-and-control } \\
\text { regulation studied and may not } \\
\text { be generalized to more flexible } \\
\text { types of regulation. }\end{array}$ \\
\hline Bloom et al., 2010 & Energy Intensity. & $\begin{array}{l}\text { Total factor } \\
\text { productivity, } \\
\text { Quality of } \\
\text { management. }\end{array}$ & $\begin{array}{l}300 \text { manufacturing firms in } \\
\text { the UK. } \\
\text { UK establishment-level } \\
\text { Census of Production data } \\
\text { from the UK ONS (license), } \\
\text { survey collected by Center } \\
\text { for Economic Performance } \\
\text { (CEP). }\end{array}$ & $\begin{array}{l}\text { Cross-section } \\
\text { (Management } \\
\text { Survey Data from } \\
\text { 2006). }\end{array}$ & Correlation & $\begin{array}{l}\text { They find a robust negative } \\
\text { relationship between } \\
\text { management practices and } \\
\text { energy intensity. Improving } \\
\text { management practices from } \\
\text { the } 25 \text { th to the } 75 \text { th percentile } \\
\text { is associated with a } 17.4 \% \\
\text { reduction in energy intensity } \\
\text { and with a } 3.7 \% \text { increase in } \\
\text { total-factor productivity. They } \\
\text { also find that better economic } \\
\text { performance as measured by } \\
\text { TFP is associated with lower } \\
\text { energy intensity. The results } \\
\text { suggest that management } \\
\text { practices that are associated } \\
\text { with improved productivity are } \\
\text { not linked to worse } \\
\text { environmental performance. }\end{array}$ \\
\hline Broberg et al. 2013 & $\begin{array}{l}\text { Environmental } \\
\text { protection investment. }\end{array}$ & $\begin{array}{l}\text { Technical } \\
\text { efficiency. }\end{array}$ & $\begin{array}{l}\text { Five Swedish industries: } \\
\text { wood and wood products } \\
\text { ( } 279 \text { obs.), pulp and paper } \\
\text { ( } 304 \text { obs.), chemicals ( } 289 \\
\text { obs.), rubber and plastics } \\
\text { ( } 223 \text { obs.), basic metals (199 } \\
\text { obs.). }\end{array}$ & Panel (1999-2004). & Correlation & $\begin{array}{l}\text { They use unique data on } \\
\text { environmental protection } \\
\text { investments in the Swedish } \\
\text { manufacturing industry as a } \\
\text { proxy for environmental } \\
\text { stringency. This allows them } \\
\text { to separate investments into } \\
\text { pollution prevention and } \\
\text { pollution control. They use a }\end{array}$ \\
\hline
\end{tabular}




\begin{tabular}{|c|c|c|c|c|c|c|}
\hline & & & $\begin{array}{l}\text { Two data sources from } \\
\text { Statistics Sweden: 1) } \\
\text { Industrial Economic } \\
\text { Statistics, 2) Industries' } \\
\text { environmental protection } \\
\text { expenditure. }\end{array}$ & & & $\begin{array}{l}\text { stochastic production frontier } \\
\text { model to estimate if } \\
\text { environmental regulation } \\
\text { affects firms' production } \\
\text { efficiency. They do not find } \\
\text { support for the Porter } \\
\text { Hypothesis as they observe a } \\
\text { weak negative relationship } \\
\text { between environmental } \\
\text { investments and technical } \\
\text { efficiency. }\end{array}$ \\
\hline
\end{tabular}




\begin{tabular}{|c|c|c|c|c|c|c|}
\hline & & & & & & $\begin{array}{l}\text { ton of } \mathrm{CO} 2 \text { at negative } \$ 250 \\
\text { (i.e. } \$ 250 \text { savings per ton } \\
\text { abated) from implementing the } \\
\text { low-cost behavioural } \\
\text { interventions, which is the } \\
\text { lowest marginal abatement } \\
\text { cost so far calculated in the } \\
\text { literature. }\end{array}$ \\
\hline $\begin{array}{l}\text { Gray and Shadbegian, } \\
2003\end{array}$ & Abatement costs. & Productivity. & $\begin{array}{l}116 \text { US pulp and paper } \\
\text { plants. } \\
\text { Longitudinal Research } \\
\text { Database (LRD) containing } \\
\text { data from the Annual Survey } \\
\text { of Manufacturers and the } \\
\text { Census of Manufacturers } \\
\text { linked together, PACE } \\
\text { survey for annual abatement } \\
\text { cost data. }\end{array}$ & Panel (1979-1990). & Correlation & $\begin{array}{l}\text { They test whether the impact } \\
\text { of environmental regulation on } \\
\text { productivity differs by plant } \\
\text { vintage and technology. Plants } \\
\text { with higher pollution } \\
\text { abatement costs have } \\
\text { significantly lower } \\
\text { productivity levels. The effect } \\
\text { depends strongly on plants' } \\
\text { technology. The negative } \\
\text { relationship between higher } \\
\text { abatement costs and lower } \\
\text { productivity levels is largely } \\
\text { driven by mills, which } \\
\text { incorporate a pulping process. } \\
\text { They show a strong negative } \\
\text { impact of abatement cost on } \\
\text { productivity. For mills without } \\
\text { such technology the impact is } \\
\text { negligible. }\end{array}$ \\
\hline $\begin{array}{l}\text { Horbach and } \\
\text { Rennings, } 2013\end{array}$ & $\begin{array}{l}\text { Cleaner Production } \\
\text { innovations, } \\
\text { Environmental end- } \\
\text { of-pipe innovations. }\end{array}$ & $\begin{array}{l}\text { Employment at } \\
\text { the firm level. }\end{array}$ & $\begin{array}{l}\text { Between } 3700 \text { and } 4500 \\
\text { German firms from the } \\
\text { Community Innovation } \\
\text { Survey (CIS), covering } \\
\text { mining and quarrying, } \\
\text { manufacturing, energy and }\end{array}$ & $\begin{array}{l}\text { Cross-section } \\
\text { (Community } \\
\text { Innovation Survey } \\
2009 \text { ). }\end{array}$ & Correlation & $\begin{array}{l}\text { The realization of } \\
\text { environmental process } \\
\text { innovations leads to a higher } \\
\text { employment within the firm. } \\
\text { Furthermore, material and } \\
\text { energy savings are positively }\end{array}$ \\
\hline
\end{tabular}




\begin{tabular}{|c|c|c|c|c|c|c|}
\hline & & & $\begin{array}{l}\text { water supply, large number } \\
\text { of service sectors. } \\
2009 \text { wave of the German } \\
\text { Community Innovation } \\
\text { Survey (CIS). }\end{array}$ & & & $\begin{array}{l}\text { correlated to employment } \\
\text { because they help to increase } \\
\text { the profitability and } \\
\text { competitiveness of the firm. } \\
\text { Yet, end-of-pipe technologies } \\
\text { (in particular air and water } \\
\text { process innovations) have a } \\
\text { negative impact on } \\
\text { employment. }\end{array}$ \\
\hline $\begin{array}{l}\text { Kumar and Managi, } \\
2010\end{array}$ & SO2 emissions price. & $\begin{array}{l}\text { Innovation } \\
\text { activity. }\end{array}$ & $\begin{array}{l}50 \text { electricity generating } \\
\text { plants. } \\
\text { Federal Energy Regulatory } \\
\text { Commission (FERC) for } \\
\text { electricity production at the } \\
\text { plant level, employees and } \\
\text { capital stock, US EPA } \\
\text { Aerometric Information } \\
\text { Retrieval System (AIRS) } \\
\text { database for SO2 emissions } \\
\text { and emissions prices. }\end{array}$ & Panel (1995-2007). & Correlation & $\begin{array}{l}\text { The authors have tested } \\
\text { whether an increase in } \mathrm{SO} 2 \\
\text { emissions prices leads to a } \\
\text { reduction in pollution } \\
\text { emissions. They observe that } \\
\text { electricity generating plants } \\
\text { experience positive induced } \\
\text { technological change. } \\
\text { Electricity-generating plants } \\
\text { are able to increase electricity } \\
\text { output and reduce emissions of } \\
\text { SO2 and NOx from } 1995 \text { to } \\
2007 \text { due to the introduction of } \\
\text { the allowance trading system. }\end{array}$ \\
\hline Martin et al., 2012 & $\begin{array}{l}\text { Energy intensity } \\
\text { (energy expenditure / } \\
\text { gross output) and } \\
\text { (energy intensity / } \\
\text { variable cost); } \\
\text { Composite Index on } \\
\text { management practices } \\
\text { related to climate } \\
\text { change collected } \\
\text { through interviews. }\end{array}$ & Productivity & $\begin{array}{l}\text { 190 UK manufacturing } \\
\text { plants. } \\
\text { ORBIS database for random } \\
\text { selection of UK } \\
\text { manufacturing plants. } \\
\text { Survey data collected by } \\
\text { authors. }\end{array}$ & $\begin{array}{l}\text { Cross-section } \\
\text { (interview data } \\
\text { collected in 2009). }\end{array}$ & Correlation & $\begin{array}{l}\text { Climate friendly management } \\
\text { practices, as measured by an } \\
\text { index constructed from survey } \\
\text { responses are associated with } \\
\text { lower energy intensity and } \\
\text { higher productivity at the } \\
\text { establishment level. They } \\
\text { suggest that there might be a } \\
\text { win-win scenario from } \\
\text { improving environmental }\end{array}$ \\
\hline
\end{tabular}




\begin{tabular}{|c|c|c|c|c|c|c|}
\hline & & & & & & $\begin{array}{l}\text { management, which could also } \\
\text { raise firm productivity. }\end{array}$ \\
\hline $\begin{array}{l}\text { Pfeiffer and Rennings, } \\
2001\end{array}$ & $\begin{array}{l}\text { Environmental } \\
\text { Innovations. }\end{array}$ & $\begin{array}{l}\text { Employment at } \\
\text { the firm level. }\end{array}$ & $\begin{array}{l}419 \text { German } \\
\text { environmentally innovative } \\
\text { manufacturing firms (a } \\
\text { company was defined as } \\
\text { such if it carried out at least } \\
\text { one environmental } \\
\text { innovation between } 1993 \\
\text { and 1995). } \\
\text { Survey of the Mannheim } \\
\text { Innovation Panel (licence). }\end{array}$ & $\begin{array}{l}\text { Cross-section } \\
\text { (1996 wave of the } \\
\text { Mannheim } \\
\text { Innovation Panel). }\end{array}$ & Correlation & $\begin{array}{l}\text { Cleaner production processes } \\
\text { are more likely to increase } \\
\text { employment compared to end- } \\
\text { of-pipe technologies. The } \\
\text { authors conclude that the } \\
\text { transition from end-of-pipe } \\
\text { technologies to cleaner } \\
\text { production can lead to a net } \\
\text { creation of jobs. }\end{array}$ \\
\hline $\begin{array}{l}\text { Sanchez-Vargas et al. } \\
\text { (2013) }\end{array}$ & $\begin{array}{l}\text { Environmental } \\
\text { regulation (as } \\
\text { measured by plant's } \\
\text { pollution abatement } \\
\text { expenditures). }\end{array}$ & Productivity & $\begin{array}{l}903 \text { observations of Mexican } \\
\text { firms. } \\
\text { Data from the national } \\
\text { industrial survey in Mexico } \\
\text { by the Mexican Statistics } \\
\text { agency. }\end{array}$ & $\begin{array}{l}\text { Cross-section } \\
\text { (2002). }\end{array}$ & Correlation & $\begin{array}{l}\text { They find a non-linear } \\
\text { relationship between } \\
\text { environmental regulation and } \\
\text { productivity. They find that a } \\
\text { decreasing trade-off between } \\
\text { productivity and } \\
\text { environmental regulation. } \\
\text { Moreover, the relationship } \\
\text { depends on the plant size and } \\
\text { the trade-off is more important } \\
\text { for small firms and a nearly } \\
\text { negligible one for larger ones. }\end{array}$ \\
\hline $\begin{array}{l}\text { Shadbegian and Gray, } \\
2003\end{array}$ & $\begin{array}{l}\text { Air pollution } \\
\text { (Particulate Matter, } \\
\text { Sulphur Dioxide) per } \\
\text { unit of output. }\end{array}$ & Productivity & $\begin{array}{l}68 \text { US pulp and paper mills. } \\
\text { Longitudinal Research } \\
\text { Database (LRD) (licence), } \\
\text { PACE for pollution } \\
\text { abatement costs. }\end{array}$ & $\begin{array}{l}\text { Cross-section (year } \\
\text { 1985). }\end{array}$ & Correlation & $\begin{array}{l}\text { The authors analyse the link } \\
\text { between firm productivity and } \\
\text { pollution abatement. They find } \\
\text { that plants with a } 10 \text { percent } \\
\text { higher productivity have } 2.5 \\
\text { percent lower emissions, } \\
\text { suggesting that productive } \\
\text { efficiency and pollution } \\
\text { abatement efficiency are }\end{array}$ \\
\hline
\end{tabular}




\begin{tabular}{|c|c|c|c|c|c|c|}
\hline & & & & & & $\begin{array}{l}\text { complements. Better managers } \\
\text { are better at both production } \\
\text { and abatement, rather than } \\
\text { concentrating on productive } \\
\text { efficiency at the expense of } \\
\text { abatement performance. }\end{array}$ \\
\hline $\begin{array}{l}\text { Shadbegian and Gray, } \\
2005\end{array}$ & $\begin{array}{l}\text { Pollution abatement } \\
\text { expenditure. }\end{array}$ & Productivity & $\begin{array}{l}68 \text { US pulp and paper mills, } \\
55 \text { oil refineries, and } 27 \text { steel } \\
\text { mills. } \\
\text { Longitudinal Research } \\
\text { Database (LRD) for } \\
\text { economic outcomes } \\
\text { (licence), } \\
\text { PACE for pollution } \\
\text { abatement costs. }\end{array}$ & Panel (1979-1990). & Correlation & $\begin{array}{l}\text { The authors analyse the impact } \\
\text { of traditional environmental } \\
\text { regulation on productivity in } \\
\text { U.S. paper mills, oil refineries, } \\
\text { and steel mills. They find that } \\
\text { pollution abatement } \\
\text { contributes little or nothing to } \\
\text { firms' productivity. }\end{array}$ \\
\hline $\begin{array}{l}\text { Shadbegian and Gray, } \\
2006\end{array}$ & $\begin{array}{l}\text { Air pollution } \\
\text { (Particulate Matter, } \\
\text { Sulphur Dioxide), } \\
\text { water pollution } \\
\text { (biological oxygen } \\
\text { demand, total } \\
\text { suspended solids), } \\
\text { toxic releases; all in } \\
\text { per unit of plant } \\
\text { output. }\end{array}$ & $\begin{array}{l}\text { Production } \\
\text { efficiency } \\
\text { (measured through } \\
\text { stochastic frontier } \\
\text { production } \\
\text { models). }\end{array}$ & $\begin{array}{l}\text { plants in } 327 \text { pulp and paper } \\
\text { mills, } 121 \text { oil refineries, and } \\
83 \text { steel mills; } \\
\text { Longitudinal Research } \\
\text { Database (LRD) (licence), } \\
\text { Census Bureau's Boston } \\
\text { Research Data Center } \\
\text { (licence), } \\
\text { Firm financial data from } \\
\text { Compustat, PACE survey } \\
\text { for abatement costs, } \\
\text { environmental performance } \\
\text { measures come from several } \\
\text { EPA databases: National } \\
\text { Emissions Inventory (NEI), } \\
\text { Permit Compliance System } \\
\text { (PCS), Toxic Release } \\
\text { Inventory (TRI), and }\end{array}$ & Panel (1990-2000). & Correlation & $\begin{array}{l}\text { There is a positive correlation } \\
\text { between the environmental and } \\
\text { economic performance at the } \\
\text { plant level. The finding } \\
\text { suggests the importance of } \\
\text { unmeasured characteristics that } \\
\text { improve both the plant's } \\
\text { environmental performance } \\
\text { and its economic performance. }\end{array}$ \\
\hline
\end{tabular}




\begin{tabular}{|c|c|c|c|c|c|c|}
\hline & & & $\begin{array}{l}\text { Compliance Data System } \\
\text { (CDS). }\end{array}$ & & & \\
\hline $\begin{array}{l}\text { van Leeuwen and } \\
\text { Mohnen, } 2017\end{array}$ & $\begin{array}{l}\text { Eco-innovations } \\
\text { (process-, and end-of- } \\
\text { pipe). }\end{array}$ & $\begin{array}{l}\text { Total factor } \\
\text { productivity. }\end{array}$ & $\begin{array}{l}\text { Approximately } 2000 \text { Dutch } \\
\text { manufacturing firms. } \\
\text { Environmental Cost of } \\
\text { Firms (ECF) survey for eco- } \\
\text { innovations, Community } \\
\text { Innovation Survey (CIS) for } \\
\text { existence or anticipation of } \\
\text { environmental regulation } \\
\text { and for environmental } \\
\text { innovation targets, } \\
\text { Production Statistics Survey } \\
\text { for production and financial } \\
\text { firm data. }\end{array}$ & $\begin{array}{l}\text { Panel (2003-2008) } \\
\text { yearly, but with } \\
\text { imputation. }\end{array}$ & Correlation & $\begin{array}{l}\text { There is a significantly } \\
\text { positive correlation between } \\
\text { existing or anticipated } \\
\text { environmental regulation and } \\
\text { eco-innovations. Moreover, } \\
\text { they observe that production } \\
\text { process eco-innovations are } \\
\text { positively correlated with } \\
\text { firms' productivity, whereas } \\
\text { end-of-pipe innovations are } \\
\text { negatively correlated with } \\
\text { firms' productivity. }\end{array}$ \\
\hline $\begin{array}{l}\text { Delmas and Pekovic, } \\
2013\end{array}$ & $\begin{array}{l}\text { Adoption of } \\
\text { environmental } \\
\text { standards (ISO14001, } \\
\text { organic labelling, fair } \\
\text { trade labelling, other } \\
\text { types of } \\
\text { environmental-related } \\
\text { standards). }\end{array}$ & $\begin{array}{l}\text { Labour } \\
\text { productivity. }\end{array}$ & $\begin{array}{l}10.663 \text { employees from } \\
5220 \text { firms. } \\
\text { French Organizational } \\
\text { Changes and } \\
\text { Computerization (COI) } 2006 \\
\text { survey, Annual Enterprise } \\
\text { Survey (EAE), Annual } \\
\text { Statement of Social Data } \\
\text { (DADS). }\end{array}$ & $\begin{array}{l}\text { Cross-section } \\
(2006) \text {. }\end{array}$ & Correlation & $\begin{array}{l}\text { Firms that have adopted } \\
\text { environmental standards enjoy } \\
\text { a one standard deviation } \\
\text { higher labour productivity } \\
\text { compared to firms that have } \\
\text { not adopted such standards. } \\
\text { Furthermore, the adoption of } \\
\text { such standards is associated } \\
\text { with increased employee } \\
\text { training and interpersonal } \\
\text { contacts, which can in turn } \\
\text { contribute to improved labour } \\
\text { productivity. }\end{array}$ \\
\hline Grolleau et al., 2012 & $\begin{array}{l}\text { Adoption of } \\
\text { environmental } \\
\text { standards (ISO14001, } \\
\text { organic labelling, fair } \\
\text { trade labelling, other } \\
\text { types of }\end{array}$ & $\begin{array}{l}\text { Self-reported } \\
\text { difficulties in } \\
\text { recruiting } \\
\text { professional and } \\
\text { non-professional } \\
\text { staff. }\end{array}$ & $\begin{array}{l}10.840 \text { French firms. } \\
\text { French Organizational } \\
\text { Changes and } \\
\text { Computerization's (COI) } \\
2006 \text { survey, Annual }\end{array}$ & $\begin{array}{l}\text { Cross-section } \\
(2006) \text {. }\end{array}$ & Correlation & $\begin{array}{l}\text { The adoption of voluntary } \\
\text { environmental standards is } \\
\text { associated with reduced self- } \\
\text { reported difficulties in the } \\
\text { recruitment of professional and } \\
\text { non-professional employees. }\end{array}$ \\
\hline
\end{tabular}




\begin{tabular}{|c|c|c|c|c|c|c|}
\hline & $\begin{array}{l}\text { environmental-related } \\
\text { standards). }\end{array}$ & & $\begin{array}{l}\text { Statement of Social Data } \\
\text { (DADS) and the Annual } \\
\text { Enterprise Survey (EAE) for } \\
\text { information on wages and } \\
\text { export respectively. }\end{array}$ & & & \\
\hline $\begin{array}{l}\text { Lanfranchi and } \\
\text { Pekovic, } 2012\end{array}$ & $\begin{array}{l}\text { Firm registration with } \\
\text { at least one } \\
\text { environmental } \\
\text { standard (ISO14001, } \\
\text { organic labelling or } \\
\text { fair trade labelling). }\end{array}$ & $\begin{array}{l}\text { Self-reported } \\
\text { employee attitudes } \\
\text { (usefulness to } \\
\text { others, equitable } \\
\text { recognition for } \\
\text { work, employee's } \\
\text { involvement, } \\
\text { absence of } \\
\text { compensation for } \\
\text { supplementary } \\
\text { work hours). }\end{array}$ & $\begin{array}{l}11600 \text { employees at } 7700 \\
\text { French firms from a } \\
\text { representative French } \\
\text { employer-employee dataset } \\
\text { of firms with more than } 20 \\
\text { employees. } \\
\text { French Organizational } \\
\text { Change and ICT's (COI) } \\
2006 \text { survey, French } \\
\text { Organizational Change and } \\
\text { ICT's (COI) } 2006 \text { survey for } \\
\text { employee compensation, } \\
\text { Annual Enterprise Survey } \\
\text { (EAE) for firm export levels. }\end{array}$ & $\begin{array}{l}\text { Cross-section } \\
\text { (2006 survey). }\end{array}$ & Correlation & $\begin{array}{l}\text { Employees of firms that have } \\
\text { adopted voluntary } \\
\text { environmental standards report } \\
\text { a significantly higher feeling } \\
\text { of usefulness at work. Firms' } \\
\text { registration for environmental- } \\
\text { related standards is associated } \\
\text { with higher feelings of } \\
\text { usefulness to others and } \\
\text { feelings of being equitably } \\
\text { recognized among the } \\
\text { employees. While the } \\
\text { employees do not claim to be } \\
\text { more involved in their jobs, } \\
\text { they are more likely to work } \\
\text { uncompensated for } \\
\text { supplementary work hours } \\
\text { compared to workers in non- } \\
\text { green firms. }\end{array}$ \\
\hline $\begin{array}{l}\text { Nyborg and Zhang, } \\
2013\end{array}$ & $\begin{array}{l}\text { Corporate Social } \\
\text { Responsibility (CSR) } \\
\text { reputation rating } \\
\text { collected through a } \\
\text { survey. Respondents } \\
\text { stated whether they } \\
\text { associate a given firm } \\
\text { with CSR activities. } \\
\text { This response was } \\
\text { combined with the }\end{array}$ & Employee wages. & $\begin{array}{l}100.000 \text { Norwegian } \\
\text { employees. } \\
\text { Young Professionals Survey } \\
\text { and Graduate Student survey } \\
\text { conducted by Universum } \\
\text { (commercial), official } \\
\text { Norwegian employee- } \\
\text { employer register for wages } \\
\text { (licence). }\end{array}$ & $\begin{array}{l}\text { Cross-section } \\
(2007) .\end{array}$ & Correlation & $\begin{array}{l}\text { Firms with higher CSR ratings } \\
\text { pay substantially and } \\
\text { significantly lower wages. The } \\
\text { authors therefore conclude that } \\
\text { even if CSR is associated with } \\
\text { higher costs (e.g. higher } \\
\text { emission abatement expenses), } \\
\text { responsible firms are still able } \\
\text { to compete in the market even }\end{array}$ \\
\hline
\end{tabular}




\begin{tabular}{|c|c|c|c|c|c|c|}
\hline & $\begin{array}{l}\text { respondent's opinion } \\
\text { on whether they } \\
\text { consider the firm an } \\
\text { "ideal employer" to } \\
\text { obtain a relative CSR } \\
\text { reputation score. }\end{array}$ & & & & & $\begin{array}{l}\text { in the absence of ethical } \\
\text { consumers or investors. }\end{array}$ \\
\hline Attig et al., 2013 & $\begin{array}{l}\text { Corporate Social } \\
\text { Responsibility (CSR) } \\
\text { score provided by a } \\
\text { third party research } \\
\text { company. }\end{array}$ & $\begin{array}{l}\text { Firm credit ratings } \\
\text { (compiled by } \\
\text { S\&P). }\end{array}$ & $\begin{array}{l}1585 \text { US firms. } \\
\text { S\&P credit ratings, } \\
\text { Compustat, Center for } \\
\text { Research in Security Prices } \\
\text { database (CRSP), } \\
\text { Thompson's Institutional } \\
\text { Brokers Estimate System, } \\
\text { MSCI ESG Stats. }\end{array}$ & Panel (1991-2010). & Correlation & $\begin{array}{l}\text { The authors find a significant } \\
\text { positive impact of CSR on } \\
\text { firm credit ratings. They } \\
\text { suggest that by investing in } \\
\text { CSR, firms' financing costs are } \\
\text { likely to decrease due to the } \\
\text { better credit rating, which all } \\
\text { else equal should enhance firm } \\
\text { value and shareholders' value. }\end{array}$ \\
\hline Cheng et al., 2013 & $\begin{array}{l}\text { Corporate Social } \\
\text { Responsibility (CSR) } \\
\text { score provided by a } \\
\text { third party. }\end{array}$ & $\begin{array}{l}\text { Capital constraints } \\
\text { expressed through } \\
\text { five accounting } \\
\text { ratios: 1) cash } \\
\text { flow to total } \\
\text { capital, 2) market } \\
\text { to book ratio, 3) } \\
\text { debt to total } \\
\text { capital, 4) } \\
\text { dividends to total } \\
\text { capital, 5) cash } \\
\text { holdings to total } \\
\text { capital. }\end{array}$ & $\begin{array}{l}2439 \text { publicly listed firms } \\
\text { across } 49 \text { countries. } \\
\text { Thompson Reuters ASSET4 } \\
\text { database. }\end{array}$ & Panel (2002-2009). & Correlation & $\begin{array}{l}\text { Firms with better CSR } \\
\text { performance face lower capital } \\
\text { constraints. }\end{array}$ \\
\hline El Ghoul et al., 2011 & $\begin{array}{l}\text { Corporate Social } \\
\text { Responsibility (CSR) } \\
\text { ratings provided by a } \\
\text { third party research } \\
\text { company. }\end{array}$ & $\begin{array}{l}\text { Ex-ante cost of } \\
\text { equity capital } \\
\text { implied in stock } \\
\text { prices and } \\
\text { analysts' earnings } \\
\text { forecasts. }\end{array}$ & $\begin{array}{l}2809 \text { US firms; } \\
\text { Thompson Institutional } \\
\text { Brokers Earnings Services } \\
\text { for analyst forecast data, } \\
\text { Compustat North America } \\
\text { for industry affiliation and }\end{array}$ & Panel (1992-2007). & Correlation & $\begin{array}{l}\text { Firms with higher CSR scores } \\
\text { enjoy significantly lower cost } \\
\text { of equity capital. The authors } \\
\text { conclude that improved CSR } \\
\text { can enhance firm value by } \\
\text { reducing the firm's cost of }\end{array}$ \\
\hline
\end{tabular}




\begin{tabular}{|l|l|l|l|l|}
\hline & & & $\begin{array}{l}\text { financial data, KLD STATS } \\
\text { for CSR data, CRSP } \\
\text { monthly return files for } \\
\text { stock returns. }\end{array}$ & $\begin{array}{l}\text { equity capital. They argue that } \\
\text { CSR activities can enhance the } \\
\text { company's investor base by } \\
\text { attracting socially responsible } \\
\text { investors. }\end{array}$ \\
\hline $\begin{array}{l}\text { Goss and Roberts, } \\
\text { in }\end{array}$ & $\begin{array}{l}\text { Corporate Social } \\
\text { Responsibility (CSR) } \\
\text { ratings provided by a } \\
\text { third party. }\end{array}$ & $\begin{array}{l}\text { Spread basis } \\
\text { points (the amount } \\
\text { the borrower pays } \\
\text { over LIBOR for } \\
\text { each loan dollar). }\end{array}$ & $\begin{array}{l}\text { KLD Research and } \\
\text { Analytics Inc. for measure } \\
\text { of social responsibility, } \\
\text { Compustat for financial } \\
\text { information, Thompson } \\
\text { CDA spectrum for } \\
\text { institutional ownership, } \\
\text { Dealscan for loan pricing } \\
\text { data. }\end{array}$ & $\begin{array}{l}\text { Firms with social } \\
\text { responsibility concerns pay } \\
\text { between 7 und 18 basis points } \\
\text { more than firms that are more } \\
\text { responsible. Lenders demand } \\
\text { higher yield spreads from } \\
\text { borrowers with the worst } \\
\text { records in social responsibility. } \\
\text { Yet, they recognize } \\
\text { greenwashing activities and } \\
\text { punish CSR activities that are } \\
\text { unlikely to add value. }\end{array}$ \\
\hline
\end{tabular}

Papers reviewed in section 3: The joint impact of environmental regulations on environmental and economic performance

\begin{tabular}{|l|l|l|l|l|l|}
\hline List et al., 2003 & $\begin{array}{l}\text { Air pollution } \\
\text { (Nitrogen oxide and } \\
\text { volatile organic } \\
\text { compounds as the } \\
\text { primary chemical } \\
\text { precursors to ozone). }\end{array}$ & $\begin{array}{l}\text { Plant location } \\
\text { (openings, } \\
\text { closing, } \\
\text { expansions, } \\
\text { contractions). }\end{array}$ & $\begin{array}{l}\begin{array}{l}\text { 280 pollution-intensive } \\
\text { plants across the 62 counties } \\
\text { in New York State. }\end{array} \\
\begin{array}{l}\text { Industrial Migration File that } \\
\text { was maintained by the New } \\
\text { York State Department of } \\
\text { Economic Development. }\end{array}\end{array}$ & $\begin{array}{l}\text { Pollution-intensive plants (1980-1990). } \\
\text { respond adversely to more } \\
\text { stringent environmental } \\
\text { regulation. }\end{array}$ & $\begin{array}{l}\text { Causation } \\
\text { Wagner et al., 2014 }\end{array}$ \\
\hline $\begin{array}{l}\text { Greenhouse Gas } \\
\text { Emissions, Carbon } \\
\text { Intensity. }\end{array}$ & Employment. & $\begin{array}{l}\text { 9500 French manufacturing } \\
\text { firms (approximately 12.000 }\end{array}$ & Panel (1999-2010). & $\begin{array}{l}\text { Causation } \\
\text { French manufacturing plants } \\
\text { reduced carbon emissions by }\end{array}$ \\
\hline
\end{tabular}




\begin{tabular}{|c|c|c|c|c|c|c|}
\hline & & & $\begin{array}{l}\text { establishments) with more } \\
\text { than } 20 \text { employees. } \\
\text { EACEI (Annual survey of } \\
\text { energy consumptions in the } \\
\text { industry) for energy } \\
\text { consumption, French annual } \\
\text { business survey (Enquete } \\
\text { Annuelle des Entreprise) for } \\
\text { balance sheet data, ETS } \\
\text { transaction log for emissions } \\
\text { allowances. }\end{array}$ & & & $\begin{array}{l}15 \% \text { during Phase II ( } 2008- \\
2013) \text { compared to unregulated } \\
\text { plants. No effect has been } \\
\text { found during Phase I ( } 2005- \\
2007) \text {. They do not find } \\
\text { significant impacts on } \\
\text { employment or on emission } \\
\text { reallocation. Reductions in } \\
\text { emissions appear to be largely } \\
\text { driven by reductions in the } \\
\text { carbon-intensity of production. }\end{array}$ \\
\hline $\begin{array}{l}\text { Petrick and Wagner, } \\
2014\end{array}$ & $\begin{array}{l}\text { Carbon emissions and } \\
\text { carbon intensity. }\end{array}$ & $\begin{array}{l}\text { Employment, } \\
\text { turnover, exports. }\end{array}$ & $\begin{array}{l}1658 \text { German manufacturing } \\
\text { facilities with more than } 20 \\
\text { employees. } \\
\text { AFiD-Betriebspanel from } \\
\text { German Research Data } \\
\text { Centre (licence), CITL for } \\
\text { list of treated plants, } \\
\text { AMADEUS. }\end{array}$ & Panel (2007-2010). & Causation & $\begin{array}{l}\text { The EU ETS caused treated } \\
\text { firms (firms that were } \\
\text { regulated by the EU ETS) to } \\
\text { reduce their emissions by } 25 \text { to } \\
28 \text { percentage points more } \\
\text { than non-treated firms (non- } \\
\text { regulated firms which were } \\
\text { otherwise similar). The carbon } \\
\text { intensity of treated firms } \\
\text { declined between } 18 \text { and } 30 \\
\text { percentage points faster for EU } \\
\text { ETS firms relative to control } \\
\text { firms. Firms largely reduced } \\
\text { their carbon emissions by } \\
\text { switching from high-carbon } \\
\text { fuels to low-carbon fuels. The } \\
\text { authors find no evidence that } \\
\text { being regulated under the EU } \\
\text { ETS had a negative impact on } \\
\text { employment. The authors } \\
\text { estimate that the EU ETS } \\
\text { increased gross output between }\end{array}$ \\
\hline
\end{tabular}




\begin{tabular}{|c|c|c|c|c|c|c|}
\hline & & & & & & $\begin{array}{l}4 \text { and } 7 \text { percent for regulated } \\
\text { firms compared to non- } \\
\text { regulated firms. The evidence } \\
\text { suggests that firms responded } \\
\text { to the EU ETS regulation by } \\
\text { reducing their carbon intensity } \\
\text { and not by reducing the scale } \\
\text { of their production. }\end{array}$ \\
\hline Klemetsen et al., 2016 & $\begin{array}{l}\text { Air pollutants (CO2, } \\
\text { N2O, PFCs) all } \\
\text { measured in } \mathrm{CO} 2 \\
\text { equivalents, } \\
\text { Emissions Intensity } \\
\text { (emissions divided by } \\
\text { man hours), } \\
\text { Emissions Level. }\end{array}$ & $\begin{array}{l}\text { Value added at } \\
\text { factor prices, } \\
\text { labour } \\
\text { productivity. }\end{array}$ & $\begin{array}{l}152 \text { Norwegian plants, of } \\
\text { which } 72 \text { plants are } \\
\text { regulated by the EU ETS. } \\
\text { Annual emissions of } \\
\text { Norwegian plants from the } \\
\text { Norwegian Environment } \\
\text { Agency (licence), Statistics } \\
\text { Norway for plant level data } \\
\text { on employment, value } \\
\text { added, energy use and prices } \\
\text { (licence). }\end{array}$ & Panel (2001-2013). & $\begin{array}{l}\text { Causation } \\
\text { (yet there } \\
\text { remain } \\
\text { differences in } \\
\text { treatment and } \\
\text { control group } \\
\text { after } \\
\text { matching). }\end{array}$ & $\begin{array}{l}\text { Plants regulated under the EU } \\
\text { ETS reduced emissions by } \\
30 \% \text { in Phase II of the EU } \\
\text { ETS, but not in the other } \\
\text { phases. Plants did not reduce } \\
\text { their emissions intensity in any } \\
\text { phase. The authors find } \\
\text { positive effects on value added } \\
\text { and labour productivity for } \\
\text { plants regulated under the EU } \\
\text { ETS compared to the control } \\
\text { group. }\end{array}$ \\
\hline $\begin{array}{l}\text { Jaraite and Di Maria, } \\
2016\end{array}$ & $\begin{array}{l}\mathrm{CO} 2 \text { emissions, } \mathrm{CO} 2 \\
\text { intensity. }\end{array}$ & $\begin{array}{l}\text { Profitability, } \\
\text { Investment. }\end{array}$ & $\begin{array}{l}353 \text { Lithuanian firms ( } 41 \\
\text { ETS firms, } 312 \text { non-ETS } \\
\text { firms). } \\
\text { Sample survey of non- } \\
\text { financial enterprises (F-01) } \\
\text { from Statistics Lithuania for } \\
\text { main financial indicators. } \\
\text { EU CITL for emissions data. }\end{array}$ & Panel (2005-2010). & Causation & $\begin{array}{l}\text { During Phase I the EU ETS } \\
\text { did not cause a reduction in } \\
\text { CO2 emissions. Yet, CO2 } \\
\text { intensity decreased slightly } \\
\text { between } 2006 \text { and } 2007 \text {. They } \\
\text { find no significant effect on } \\
\text { firm profitability from the EU } \\
\text { ETS. Yet, the authors suggest } \\
\text { that the EU ETS might have } \\
\text { induced the retirement of old } \\
\text { and less efficient capital stock } \\
\text { during Phase I, and led to } \\
\text { some additional investments }\end{array}$ \\
\hline
\end{tabular}




\begin{tabular}{|c|c|c|c|c|c|c|}
\hline & & & & & & $\begin{array}{l}\text { into new capital equipment } \\
\text { from } 2010 \text {. }\end{array}$ \\
\hline Abrell et al., 2011 & CO2 emissions. & $\begin{array}{l}\text { Profits, } \\
\text { employment, } \\
\text { value added. }\end{array}$ & $\begin{array}{l}2101 \text { European firms. } \\
\text { Community Independent } \\
\text { Transaction Log (CITL) } \\
\text { collected by the European } \\
\text { Commission for emission } \\
\text { allowances, AMADEUS for } \\
\text { firm production data. }\end{array}$ & Panel (2005-2008). & Causation & $\begin{array}{l}\text { Emission reductions were } \\
3.6 \% \text { higher between } 2007 \text { and } \\
2008 \text { than between } 2005 \text { and } \\
2006 \text {, which the authors } \\
\text { attribute to the increased } \\
\text { stringency of the regulation of } \\
\text { the EU ETS. They argue that } \\
\text { the shift from Phase I to Phase } \\
\text { II of the EU ETS had a } \\
\text { significant impact on firms' } \\
\text { emission reductions. They find } \\
\text { that the EU ETS did at most } \\
\text { modestly affect profits, } \\
\text { employment and value added } \\
\text { of regulated firms. This study } \\
\text { finds a causal effect, yet they } \\
\text { take control firms only from } \\
\text { non-regulated sectors, which } \\
\text { likely introduce a selection } \\
\text { bias at the sector level). }\end{array}$ \\
\hline Martin et al., 2014a & $\begin{array}{l}\text { Energy intensity, } \\
\text { electricity use. }\end{array}$ & $\begin{array}{l}\text { Employment, } \\
\text { Revenue, Total } \\
\text { factor } \\
\text { productivity, plant } \\
\text { exit. }\end{array}$ & $\begin{array}{l}6886 \text { UK plants. } \\
\text { Annual respondents database } \\
\text { (ARD) which is maintained } \\
\text { by the Office for National } \\
\text { Statistics (licence), } \\
\text { Quarterly Fuels Inquiry } \\
\text { (QFI) for energy use } \\
\text { information, information on } \\
\text { CCA participation from both } \\
\text { DEFRA and HM Revenue } \\
\text { and Customs (HMRC) }\end{array}$ & Panel (2001-2004). & Causation & $\begin{array}{l}\text { The UK Climate Change Levy } \\
\text { had a strong negative impact } \\
\text { on energy intensity }(-18 \%) \text { and } \\
\text { electricity use }(-22.6 \%) \text {. No } \\
\text { statistically significant impacts } \\
\text { are found for employment, } \\
\text { revenue, total factor } \\
\text { productivity or plant exit. The } \\
\text { results suggest that firms } \\
\text { substituted labour for energy } \\
\text { and increased output prices in }\end{array}$ \\
\hline
\end{tabular}




\begin{tabular}{|c|c|c|c|c|c|c|}
\hline & & & $\begin{array}{l}\text { websites, European } \\
\text { Pollution Emissions Register } \\
\text { (EPER) (public). }\end{array}$ & & & $\begin{array}{l}\text { response to the energy price } \\
\text { increase. }\end{array}$ \\
\hline $\begin{array}{l}\text { Marin and Vona, } \\
2017\end{array}$ & $\begin{array}{l}\mathrm{CO} 2 \text { emissions, } \\
\text { energy consumption. }\end{array}$ & $\begin{array}{l}\text { Employment, } \\
\text { wages, } \\
\text { productivity. }\end{array}$ & $\begin{array}{l}\text { French manufacturing } \\
\text { establishments with } 61153 \\
\text { establishment-year } \\
\text { observations. } \\
\text { Datasets provided by the } \\
\text { French Statistical Office } \\
\text { (INSEE) (Licence): EACEI } \\
\text { survey on energy purchase } \\
\text { and consumption, DADS for } \\
\text { employment and wage data, } \\
\text { FARES-FICUS on firms' } \\
\text { balance sheets. }\end{array}$ & Panel (2000-2010). & Correlation & $\begin{array}{l}\text { The authors find that a } 10 \\
\text { percent increase in energy } \\
\text { prices leads to a } 6 \text { percent } \\
\text { reduction in energy } \\
\text { consumption and to an } 11 \\
\text { reduction in CO } 2 \text { emissions. } \\
\text { They find a modestly negative } \\
\text { impact on employment of } \\
\text { negative } 2.6 \text { percent and small } \\
\text { negative effects on wages and } \\
\text { productivity. The negative } \\
\text { employment effects are mostly } \\
\text { concentrated in energy- } \\
\text { intensive and trade-exposed } \\
\text { sectors. }\end{array}$ \\
\hline Lanoie et al., 2011 & $\begin{array}{l}\text { Environmental } \\
\text { performance (self- } \\
\text { reported survey } \\
\text { answer), } \\
\text { Environmental R\&D } \\
\text { (self-reported survey } \\
\text { answer). }\end{array}$ & $\begin{array}{l}\text { Business } \\
\text { performance (self- } \\
\text { reported survey } \\
\text { answer). }\end{array}$ & $\begin{array}{l}4144 \text { facilities across } 7 \\
\text { OECD countries covering } \\
\text { facilities with more than } 50 \\
\text { employees across all } \\
\text { manufacturing sectors. } \\
\text { OECD survey. }\end{array}$ & $\begin{array}{l}\text { Cross-section } \\
\text { (survey conducted } \\
\text { in 2003). }\end{array}$ & Correlation & $\begin{array}{l}\text { Using a survey across } 7 \text { OECD } \\
\text { countries, the authors obtain } \\
\text { self-reported data on } \\
\text { environmental and business } \\
\text { performance to test different } \\
\text { versions of the Porter } \\
\text { Hypothesis and its causality } \\
\text { chains. The authors find } \\
\text { support for the "weak" version } \\
\text { of the Porter Hypothesis, } \\
\text { showing that environmental } \\
\text { regulation induces innovation. } \\
\text { Furthermore, they also find } \\
\text { that more flexible } \\
\text { "performance standards" are } \\
\text { more likely to induce }\end{array}$ \\
\hline
\end{tabular}


$60 \mid \mathrm{ECO} / \mathrm{WKP}(2018) 62$

\begin{tabular}{|c|c|c|c|c|c|c|}
\hline & & & & & & $\begin{array}{l}\text { innovation than more } \\
\text { prescriptive "technology-based } \\
\text { standards". Yet, they find no } \\
\text { support for the "strong" } \\
\text { version of the Porter } \\
\text { Hypothesis. They find a } \\
\text { negative direct effect of policy } \\
\text { stringency on business } \\
\text { performance, which exceeds } \\
\text { the indirect positive effect, } \\
\text { mediated through R\&D. }\end{array}$ \\
\hline $\begin{array}{l}\text { Rexhauser and } \\
\text { Rammer, } 2014\end{array}$ & $\begin{array}{l}\text { Environmental } \\
\text { Innovation (Defined } \\
\text { as a new or } \\
\text { significantly new } \\
\text { product introduced } \\
\text { between } 2006 \text { and } \\
2008 \text { in the firm that } \\
\text { creates environmental } \\
\text { benefits compared to } \\
\text { alternatives; self- } \\
\text { reported). }\end{array}$ & Firm profitability. & $\begin{array}{l}3618 \text { German firms. } \\
\text { German part of the } \\
\text { Community Innovation } \\
\text { survey (Mannheim } \\
\text { innovation panel) (licence). }\end{array}$ & $\begin{array}{l}\text { Cross-section } \\
\text { (Survey conducted } \\
\text { in 2009). }\end{array}$ & Correlation & $\begin{array}{l}\text { The authors provide evidence } \\
\text { that environmental innovation, } \\
\text { which improves firms' } \\
\text { resource efficiency, can } \\
\text { provide positive profitability } \\
\text { effects. Yet, for any other } \\
\text { environmental innovation, } \\
\text { which does not improve } \\
\text { resource efficiency, they find } \\
\text { some weak evidence for } \\
\text { adverse profitability effects. }\end{array}$ \\
\hline
\end{tabular}

